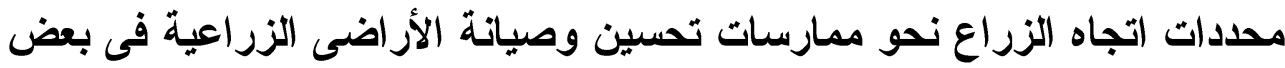 قرى محافظات البحيرة و الغربية وكفر الثيخ \\ علام محمد طنطاوى ، لمباء سعد الحسينح \\ قسم بحوث / المجتمع الريفى - معهز بحوث الإرشاد الزراعى - الجيزة - مصر \\ المستخلص | (الم
}

استهدف البحث تحديد مستوى اتجاه الزراع المبحوثين نحو ممارسات

تحسين وصيانة الأر اضى الزر اعية فى القرى المدروسة، وتحديد معنوية

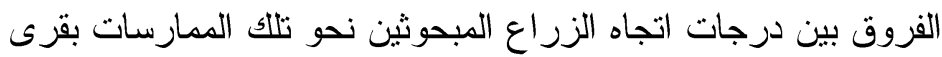

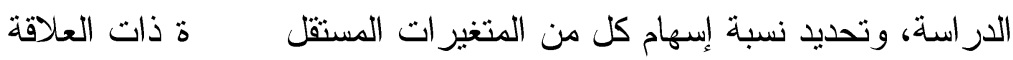

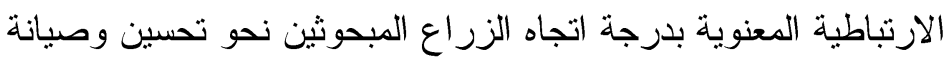

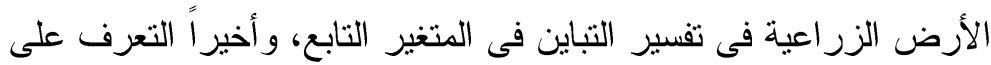

بعض مقترحات الزراع المبحوثين التى تنجعهم على تحسين وصيانة الأر اضى الزر اعية من وجهة نظرهم، ولتحقيق أهداف البحث تم اختيار عينة

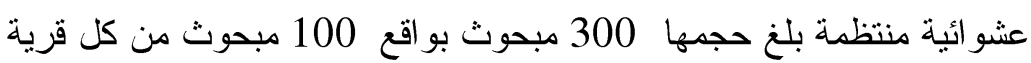
من القرى الثلاث موضع البحث. ملنه

وتم جمع البيانات الميدانية خلال شهرى مايو ويونيه 2012 بالمقابلة

الثخصية باستخدام الاستبيان و عولجت البيانات كمياً، و استخدم فى تحليلها

إحصائيا اختبار تحليل التباين، ومعامل الارتباط البسيط لبيرسون، ونموذج وعيل

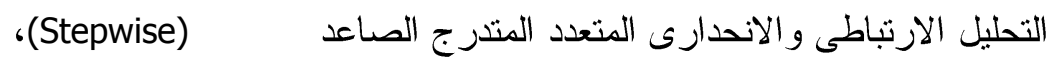

بالإضافة إلى المتوسط الحسابى، كما استخدم العرض الجدولى بالتكرار،

و النسب المئوية لعرض بعض بيانات هذا البحث.

\section{وتلخصت أهم النتائج فيما يلى:}

1 - أن ما يقرب من نصف الزر اع المبحوثين يقعون فى فئة الاتجاه الايجابى نحو ممارسات تحسين وصيانة الأر اضى الزر اعية، وان النصف الأخر من الزر اع المبحوثين يقعون فى فئتى الاتجاه المحايد و السلبى نحو تلك الممارسات.

r - نرتبط متغير ات درجة تعليم المبحوث، و عدد سنوات الخبرة فى الزر اعة، ودرجة التردد على ولى

مصادر المعلومات الزر اعية البيئية،والدخل الأسرى الثهرى، ودرجة تو افر التسهيلات

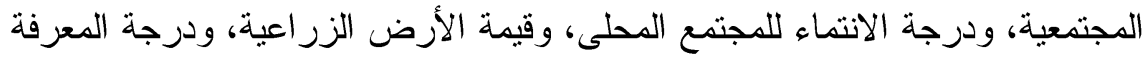

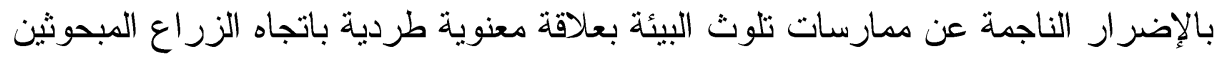
نحو ممارسات تحسين وصيانة الأر اضى الزر اعية. 
ب - ووجد أن المتغيرات المستقلة تشرح وتفسر حوالى 54\% من التباين الكلى فى درجة اتجاه

الزراع المبحوثين نحو ممارسات تحسين وصيانة الأراضى الزر اعية، إلا انه يوجد ستة

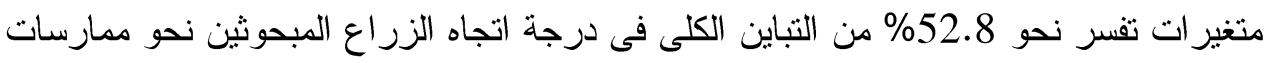

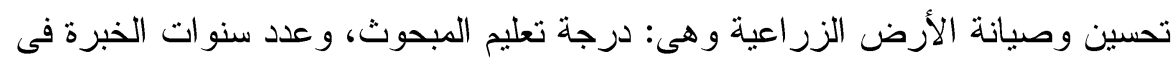

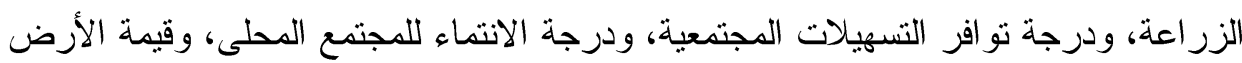
الزر اعبة، ودرجة المعرفة بالإضرار الناجمة عن ممارسات تلوث البيئة.

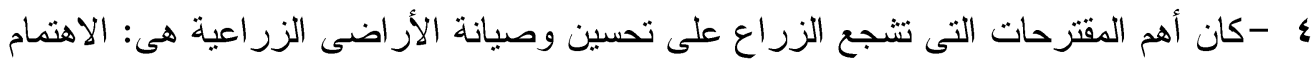

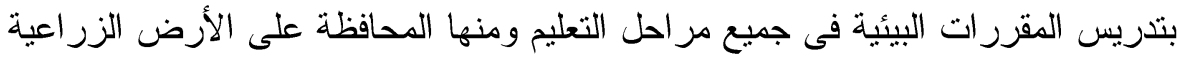

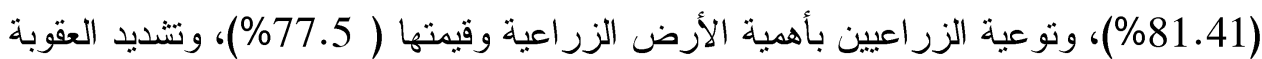

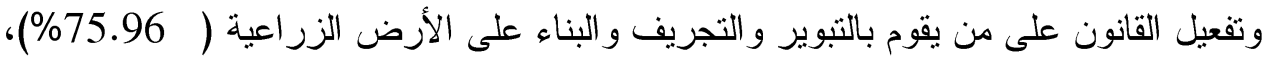

وكان أقل المقترحات أهمية هو تخصيص أماكن معينة لكل قرية لإلقاء المخلفات المنزلية

\section{مقدمة ومشكلة البحث}

لاشك أن للزر اعة فى جمهورية مصر العربية دور أساسي ومحوري خلال مختلف مهابه العصور إذ أنها تعتبر ركيزة للأمن الغذائى لافر اد المجتمع، كما أنها تمثل قطاعاً اقتصاديا هاما لتوليد الدخل لما يقرب من نصف تعداد السكان، وتستو عب قرابة 29\% من قوة العمل البشرى (مجلس الوزر اء ، 2002)، الأمر الذى يستدعى تعبئة كافة الموارد الزر اعية ووضع السياسات الاقتصادية و الاجتماعية الكفيلة بتعظيم اسهام الزر اعة فى تحقيق اهداف التتمية الزر اعية الثشاملة.

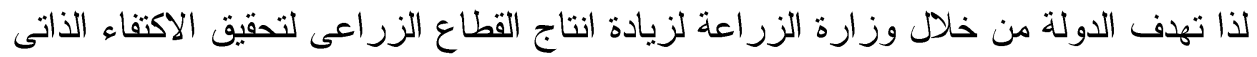

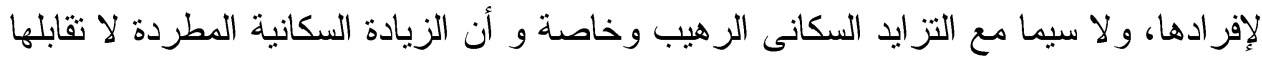

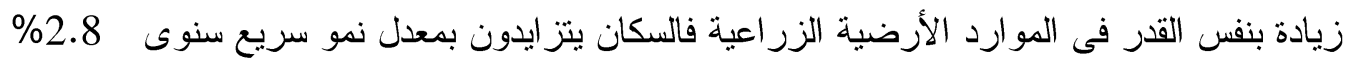

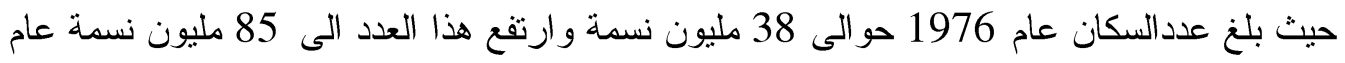
2010، و على الرغم من ذلك فان مساحة الأرض الزر اعية زادت من 5.8 مليون فدان عام 1976

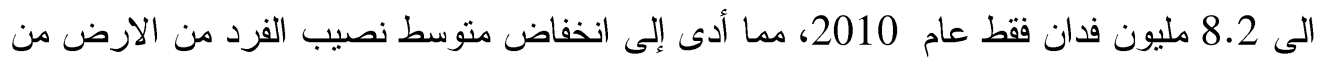
0.15 فدان عام 1976 الى 0.13 فدان عام 2010 (مجلس الوزراء، 2011). هذا وتسعى التتمية الزر اعية الرأسية بصفة رئيسية الى التغلب على عدم استغلال الموارد

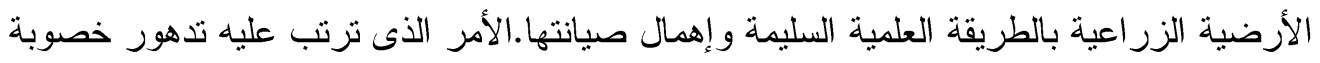

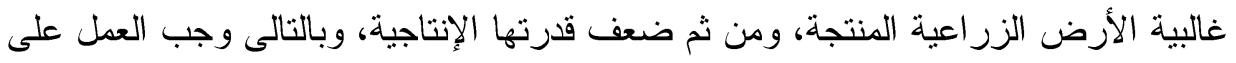
صيانتها ووقايتها ومعالجة أسباب تدهور ها الحامولى، 2003: 12) ويشير ذلك إلى أنى أن عمليات تحسين وصيانة الأر اضى الزر اعية من المرتكزات الاساسية فى تتفيذ اهداف التنمية الزر اعية

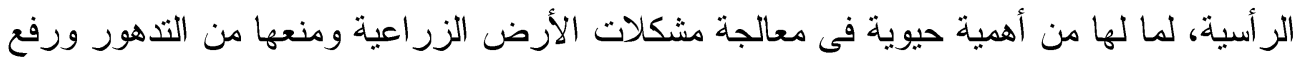

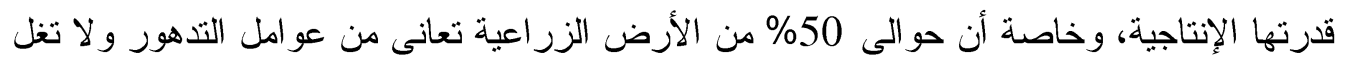

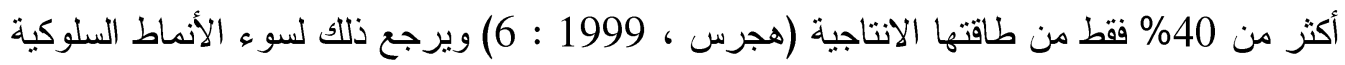


الر اهنة تجاه البيئة الريفية وخاصة الأرض الزراعية. حيث دأب الريفيون على انتهاج ممارسات بيئية غير و اعية منها تجريف التزبة الزر اعية، و التعدى عليها بالتبوير و البناء وقد زاد ذلك بعد ثورة 25

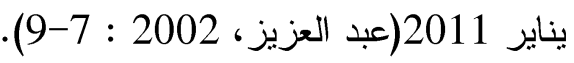

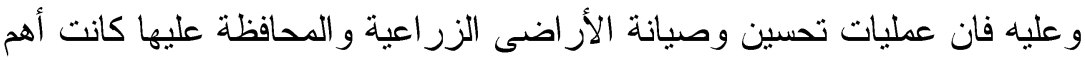

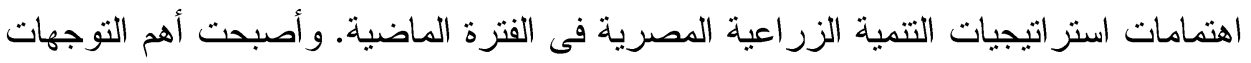

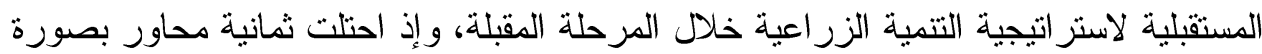
رئيسية أو ثانوية داخل استرايجية التتمية الزر اعية المصرية فى عام 2017 منمثلة فى: الاستمر ار

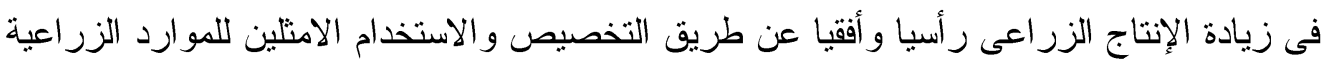

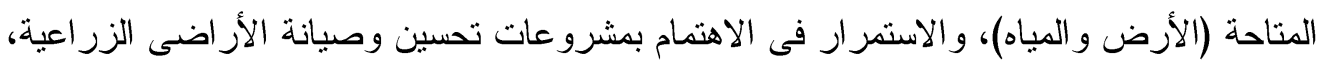

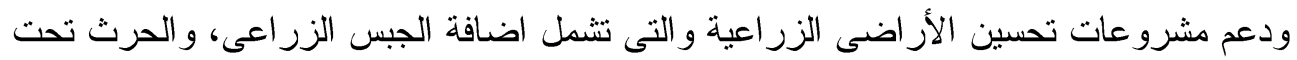

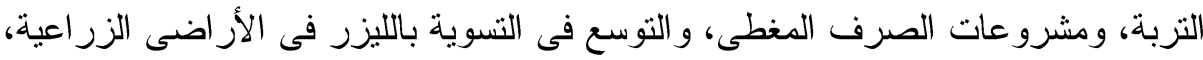

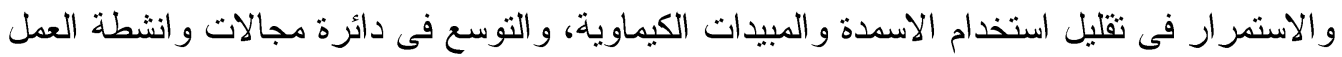
الارشادى الزر اعى فى النو احى الجديدة ومنها حماية البيئة، و المحافظة على المو ارد المائية وترشيد الئه

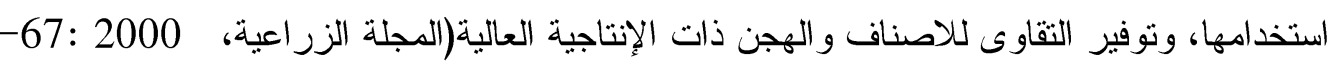

ونظراً لان الاتجاهات تعمل كموجهات لسلوك الافراد وكدو افع نحو العمل و الثعور

بالانتماء للجماعة التى يعيشون فيها ، لذا يصبح من الصعب فهم سلوك الفرد و التتبؤ بكيفيتة فى لهي موقف معين دون تحليل وتفهم اتجاهاته (Otsan \& Zanna, 1991: 196)، وبناء على ذللك يعتبر تو افق اتجاهات الزر اع تجاه ممارسات تحسين وصيانة الأراضى الزر اعية من أهم العو امل المسبية

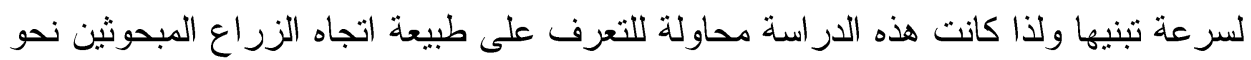

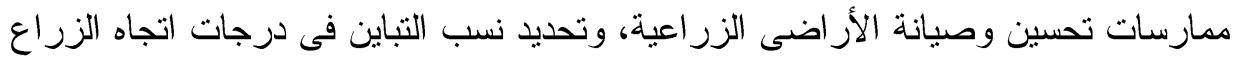
المبحوثين نحو تلك الممارسات و التى تعزى الى المتغيرات المستقلة ذات العلاقة المعنوية بها، و التعرف على بعض المقترحات من وجهة نظر الزراع المبحوثين لتحسين وصيانة أر اضيهر.

\section{أهداف البحث المثر}

\section{تمشياً مع أبعاد المشكلة السابق عرضها أمكن صياغة أهداف البحث كما يلى:}

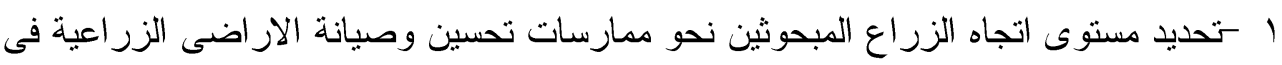

$$
\text { قرى الدراسة. }
$$

Y - تحديد الفروق بين درجات اتجاه الزراع المبحوثين نحو ممارسات تحسين وصيانة الأراضى

$$
\text { الزر اعية فى قزى الدر اسة. }
$$

r ت تحديد نسبة إسهام كل من المتغيرات المستقلة ذات العلاقة الارتباطية المعنوية بدرجة اتجاه

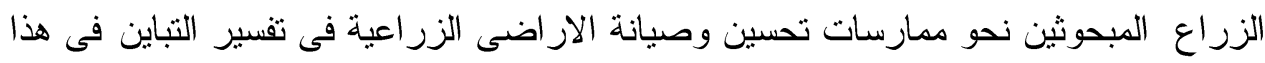


؟ - -التعرف على بعض المقترحات من وجهة نظر الزراع التى تساعدهم على تحسين وصيانة أر اضيهم.

\section{الاستعر اض المرجعى}

يعرف تحسين الأرض الزراعية بأنه تحسين عيب أو أكثر من العيوب المحددة لرفع انتاجية

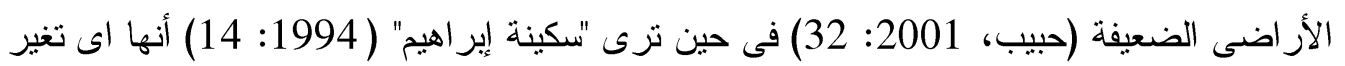
فى التربة المتدهورة المزروعة فعلا ويؤدى الى جعلها من النواحى الطبيعية و الكيمائية بيئة صالحة

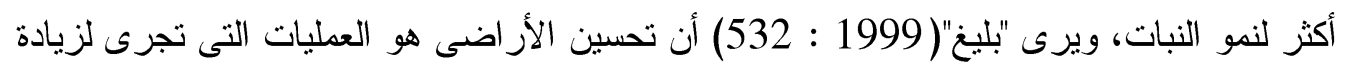

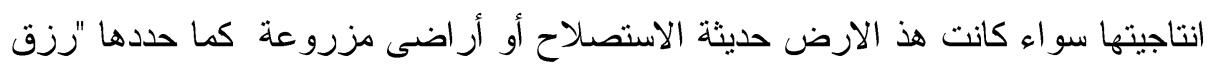

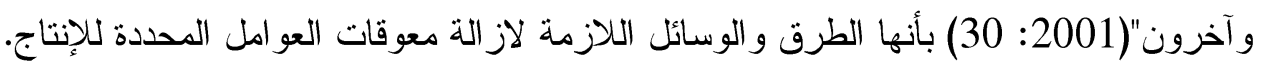

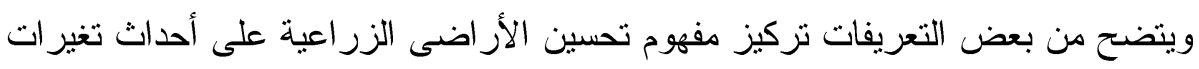

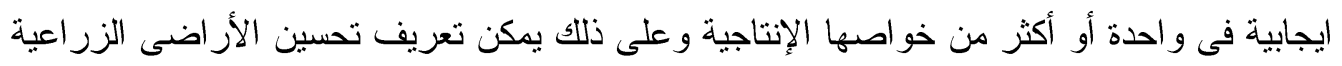

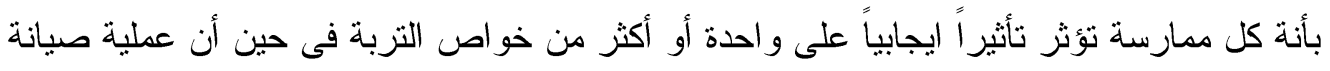

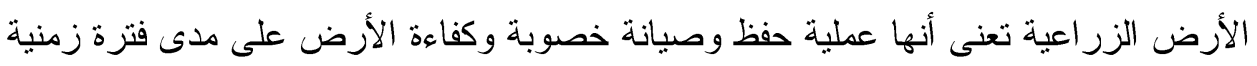

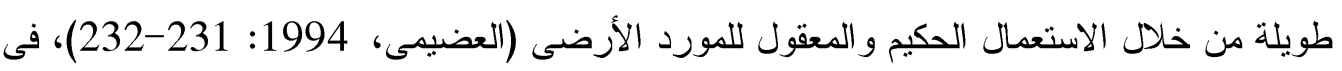

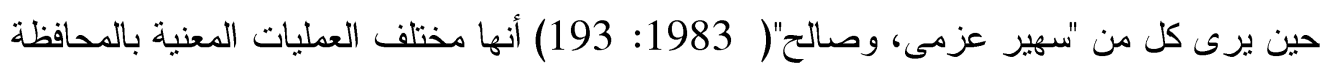

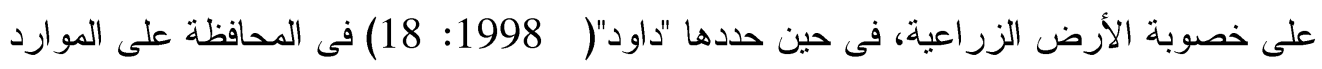

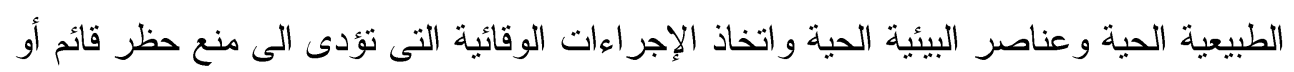

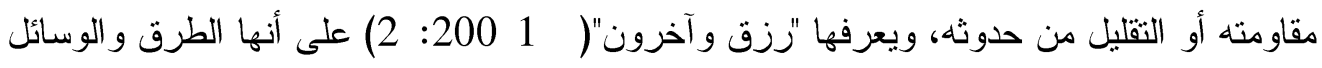

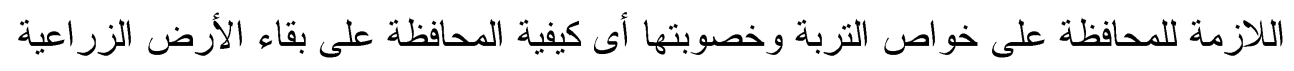
على حالتها من ناحية الانتاج العالى، بينما يرى "فواز"(

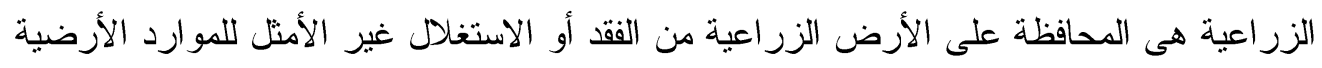

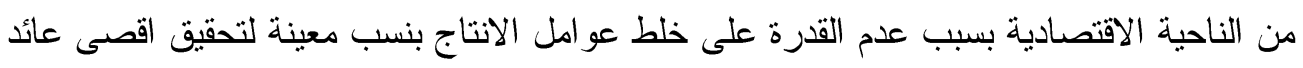

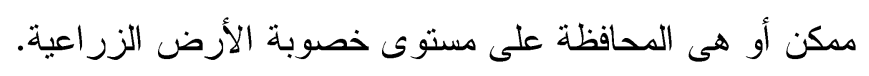

تتفق هذه التعريفات على أن مفهوم صيانة الأرض الزر اعية يتضمن منع كل ما يؤثز سلبيا

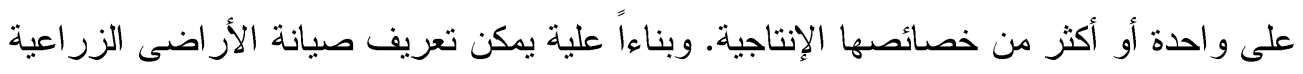

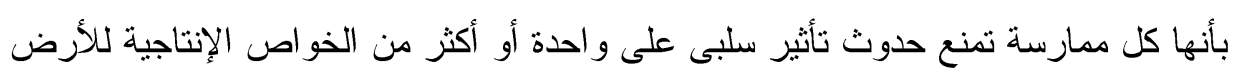

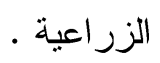

ويرى كل من أن من إجراءات صيانة التربة "Ayers \& Westcot" (1985: 27-29)

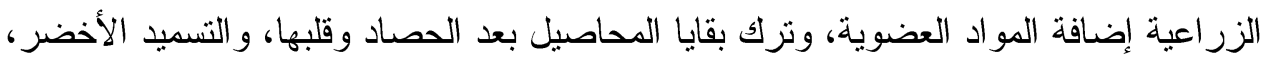

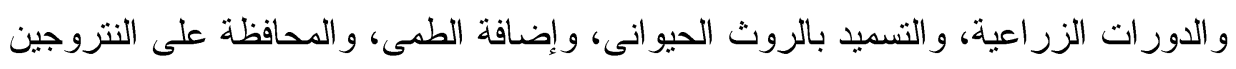
و الفوسفور بالتربة، و إمداد التربة بالبوتاسيوم و العناصر النادرة. 
ويذكر "الجبالى ومصطفى"( 1990: 845) أن مجالات تحسين وصيانة الأرض الزر اعية

تتمثل فى التخلص من ملوحة الأرض الزر اعية، و إضافة المقررات السمادية المثلى، و الالتزام

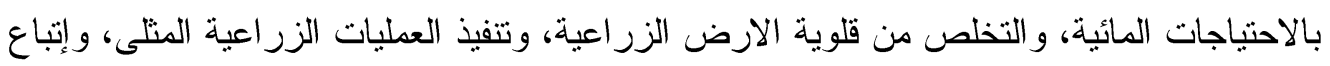

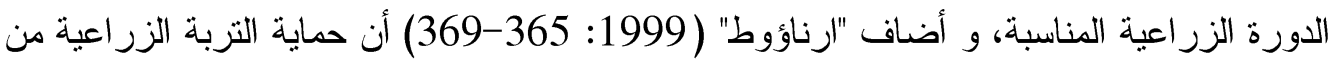
التلوث بالمبيدات من أهم عمليات التحسين من خلال استخدام الجاذبيات الجنسية، واستخدام المكافحة البيولوجية، و استخدام مثنطات نمو الحشرات، و استخدام هرمونات الانسلاخ و الزر اعة المبكرة، والخدمة الزر اعية الجيدة. ولقد سعت الدولة لإصدار العديد من القوانين

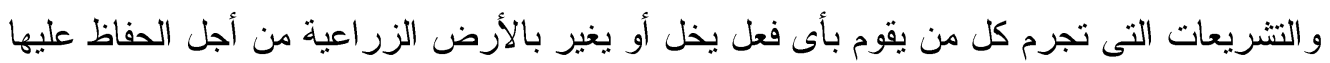
وصيانتها. وخلاصة القول انه يمكن اجمال أهم عمليات تحسين وصيانة الأراضى الزر اعية فيما يلى: الحرث

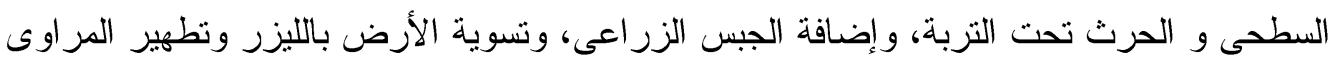

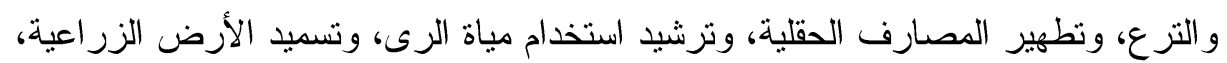

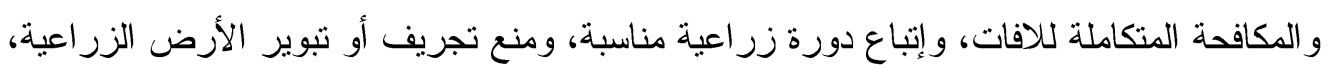
وتظوير نظم الرى، ومد نظام الصرف المغطى.

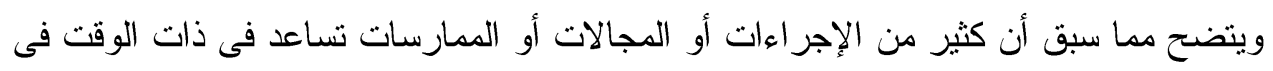

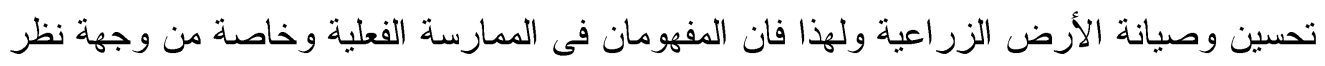

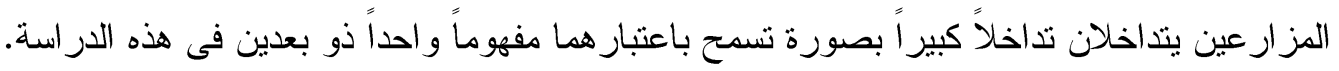

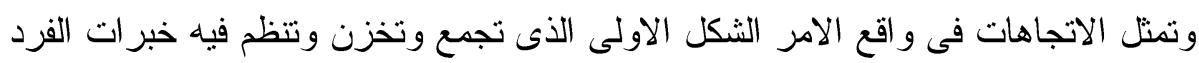
السابقة ورؤيته للمو اقف الجديدة (14-15 :Freedman, 1970) وتلعب الاتجاهات دور الهاما في وفى دفع

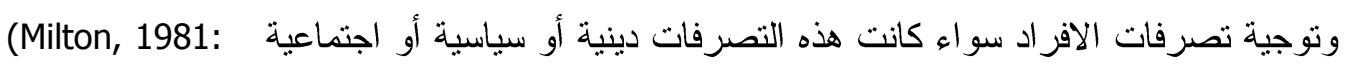
(20، فهى تؤثر فى احكامهم و ادر اكهم للاخرين وللمو اقف المحيطة بهم، كما تؤثر فى سرعة وكفاءة

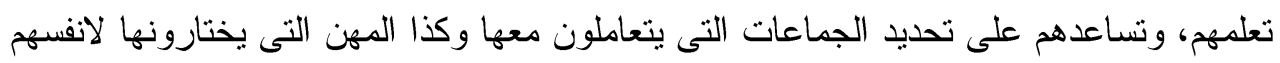

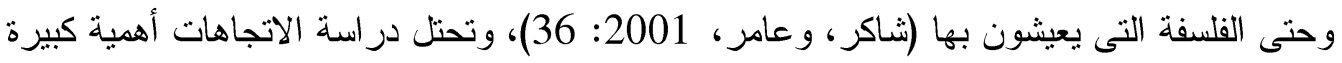
فى المجالات التطبيقية ومنها بطبيعة الحال دراسات التغير الاجتماعى فى مجال التنمية الريفية حيث

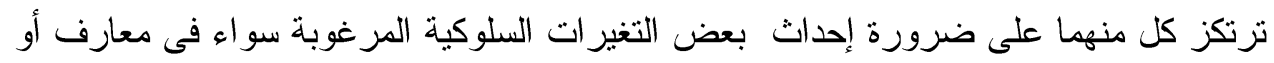
اتجاهات أو ممارسات الافراد ويتوقف عليها نجاح أو فشل العديد من الجهود التى يبذلها القائمون

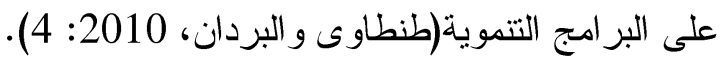
ولا ريب فى أن اتجاهات المزارعين السلبية فى حاجة ماسة الى تغييرها وذللك عن طريق

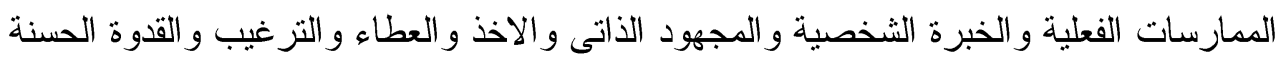

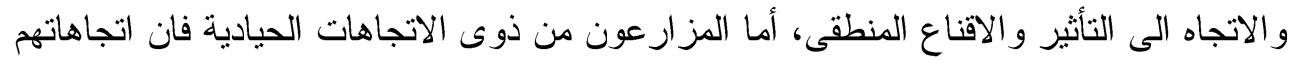

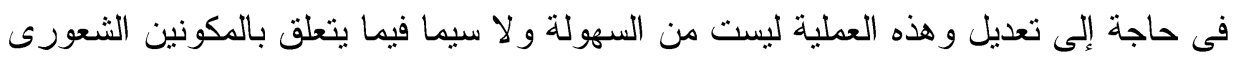
و النزوعى (سهير عزمى، وصالح، 1983). 
و اتفق معظم الباحثين على أن الاتجاه يتكون من ثلاثة مكونات هى مكون معرفى ومكون

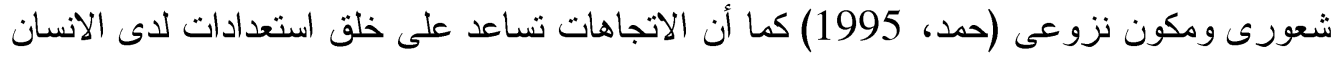

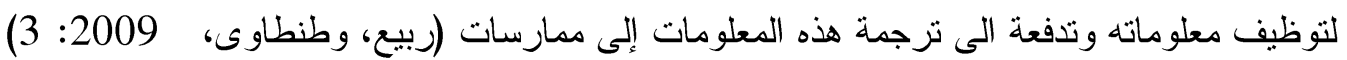
وبالتالى يمكن القول بأن معارف الافر اد و ادر اكهم للمشكلات البيئية الناجمة عن عدم تحسين صيانتهم الارض الزر اعية قد تخلق لديهم استعدادات واتجاهات ايجابية نحو تحسين وصيانة أراضيهر. ونظر الان الاتجاهات تعمل كموجهات لسلوك الإفراد، وكدو افع نحو العمل و الثُعور

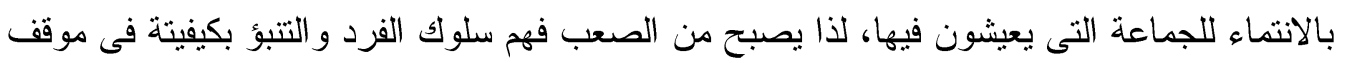

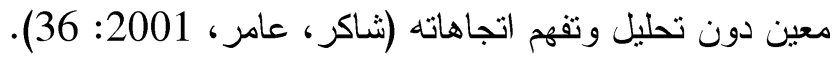

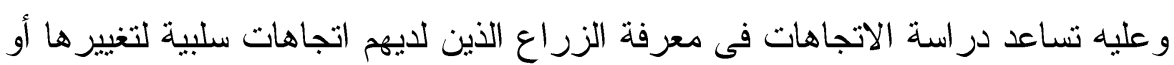

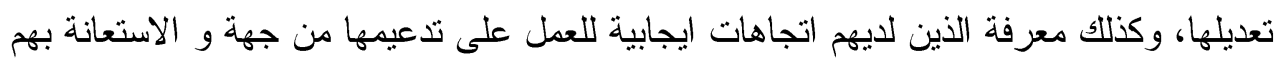

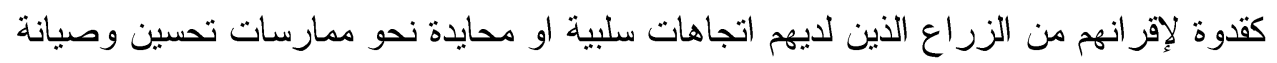
الأر اضى الزر اعية من جهة أخرى. وقد أكدت دراسة وهبه (1990) أن حو الى 69\% من عن عينة الدراسة ينسمون بتدنى ادر اكهم للاساليب الصحيحة فى التخلص من النفايات و المخلفات الزر اعية، وأن بعض الاساليب و الطرق التى ولى دولى

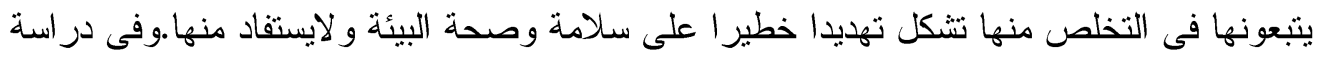

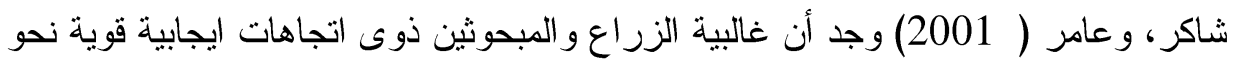

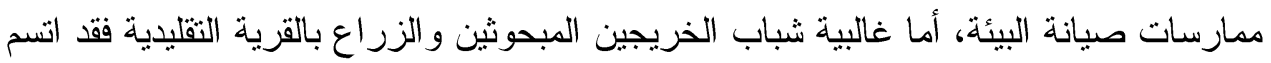
اتجاهاتهم نحو تلك الممارسات بالايجابية الضعيفة.

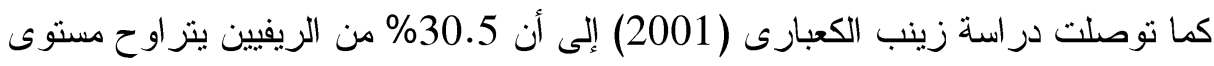

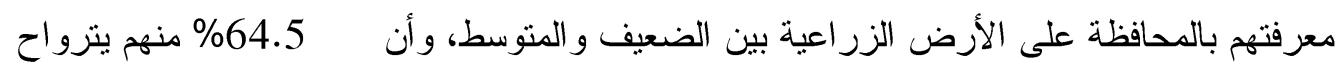
مستوى تتفيذهم لممارسات المحافظة على الأرض الزر اعية بين الضعيف و المتوسط.

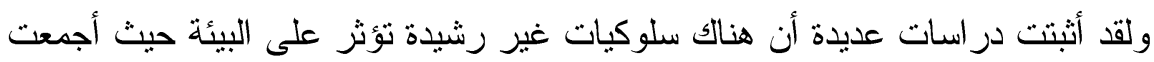
دراسات كل من عزيزة السيد ( 1996)، ووسام القصاص ( 2003)، و أمل جمعة (

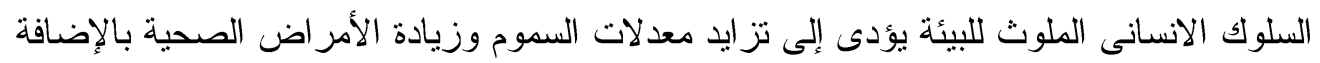
إلى تدهور و استتز اف التزبة ومياه الرى. وفى در اسة حيدق وطنطاوى ( 2009) وجد أن الغالبية العظمى من المبحوثين يقعون فى وهي

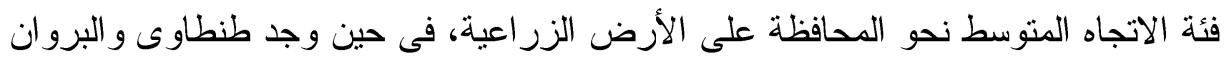

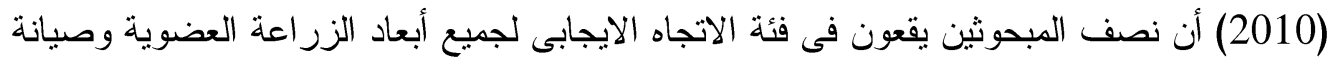

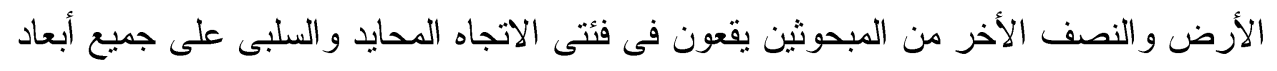

$$
\text { الزر اعة العضوية المدروسة. }
$$

و انطلاقاً من الاستعر اض السابق تعد در اسة الاتجاهات نحو ممارسات تحسين وصيانة

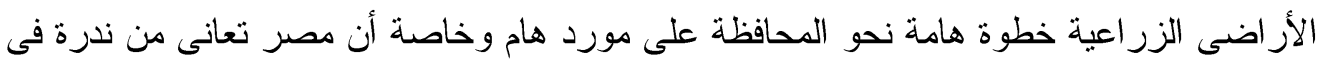


الأر اضى الزراعية الخصبة وخاصة أن هذا السلوك البيئى الملوث للأر اض القديمة يهدر من قيمتها

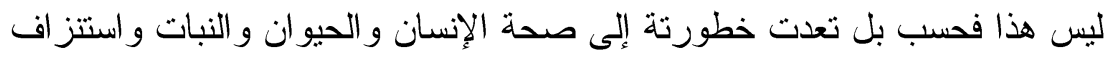

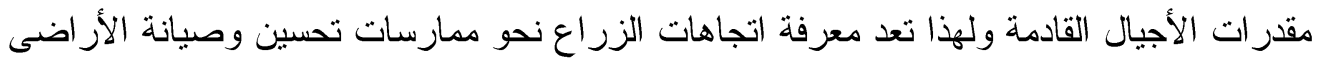
الزر اعية جديرة بالاهتمام بالبحث و الدر اسة.

\section{فروض البحث}

لتحقيق هدفى البحث الثانى والثالث، تم صياغة الفروض البحثية التالية: ا كتوجد فروق معنوية بين منوسطات درجات اتجاه الزراع المبحوثين نحو ممارسات تحسين وصيانة الأر اضى الزر اعية فى قرى الدراسة الثلاثة التالية: قرية ابو المجد، وقرية المعتمدية، وقرية محلة القصب.

r كتوجد علاقة ارتباطيه معنوية بين درجات اتجاه الزراع المبحوثين نحو ممارسات تحسين

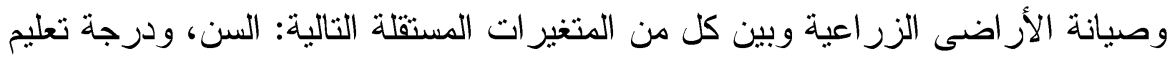
المبحوث، وعدد سنوات الخبرة فى الزر اعة، وحجم الحيازة الزر اعية، وحجم الحيازة الحيوانية، ودرجة مصادر المعلومات الزراعية البيئية، و الدخل الأسرى الثهرى، ودرجة ودئة تو افر التسهيلات

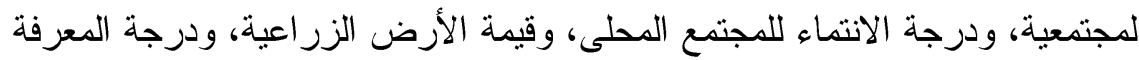

$$
\text { بالإضر ار الناجمة عن ممارسات تلوث البيأة }
$$

ب تمتوجد علاقة ارتباط متعدد معنوى بين المتغيرات المستقلة المدروسة مجتمعة، وبين اتجاه الزر اع المبحوثين نحو ممارسات تحسين وصيانة الأر اضى الزر اعية.

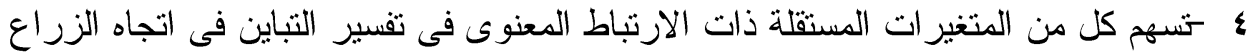
المبحوثين نحو ممارسات تحسين وصيانة الأر اضى الزر اعية .

\section{الطريقة البحثية}

أولاً: منطقة البحث وعينته

أجرى هذا البحث فى محافظات البحيرة و الغربية وكفر الثيخ، على أساس أنهم أكثر

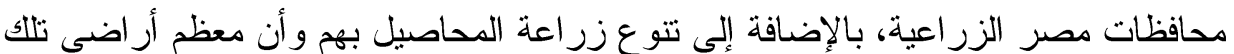

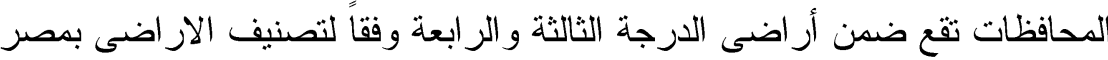

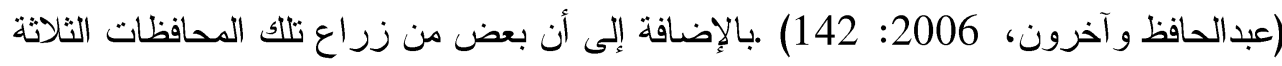

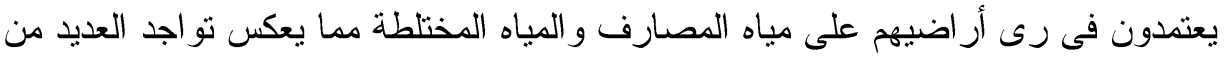
الممارسات التى تؤدى إلى التدهور فى خصائص تلك الار اضى وبالتالى تدهور إنتاجها. ومن كل

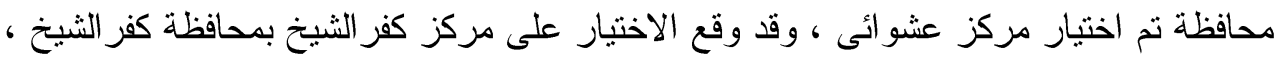
ومركز المحلة الكبرى بمحافظة الغربية، ومركز الرحمانية بمحافظة البحيرة ، ومن كل مركز تم اختيار قرية واحدة عشو ائياً وكانت القرى المختارة هى قرية محلة القصب مركز كفر الثيخ محافظة

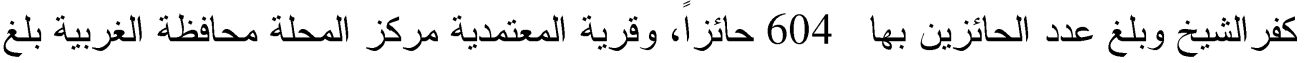
عدد الحائزين بها 526 حائز اً، وقرية ابو المجد مركز الرحمانية محافظة البحيرة، وكان عدد الحائزين

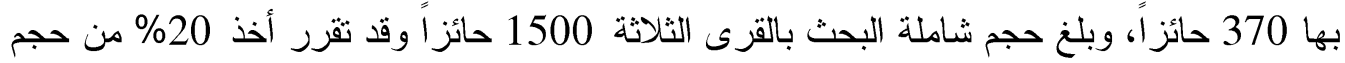


الثاملة وبذلك بلغ حجم العينة بالقزى الثلاثة 300 مبحوثا.ولتحقيق أهداف البحث تم اختيار عينة عشو ائية منتظمة بلغ قو امها 100 مبحوثاً من كل قرية مختارة. ثانياً: أداة جمع البيانات

تم جمع بيانات هذا البحث بالمقابلة الثخصية من الزراع المبحوثين باستخدام استمارة استبيان

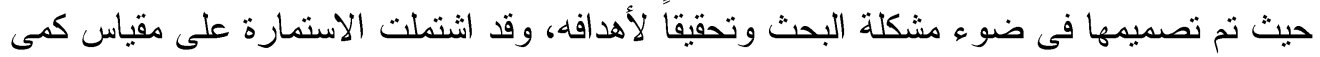

لتحديد اتجاه الزراع المبحوثين نحو ممارسات تحسين وصيانة الأر اضى الزر اعية، وقد تم إعداد المقياس على ثلاث مر احل، بالإضافة إلى الأسئلة الخاصة بالتعرف على كل من المتغيرات المستقلة

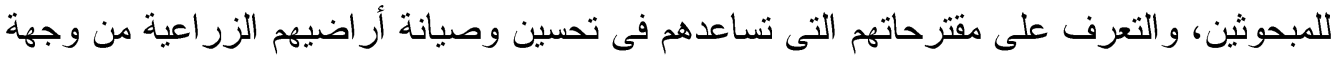
نظرهم، وبعد الانتهاء من بناء المقياس واختباره و إعداد الاستمارة بالثكل الذى يحقق أهداف البحث تم جمع البيانات ثم تفريغها وجدولتها تمهيداً لتحليلها. ثالثاً: قياس المتغير ات البات ثُبثية أ- المتغير التابع:اتجاه الزراع نحو تحسين وصيانة الار اضى الزرابه اعية: لتحديد درجة اتجاه الزر اع المبحوثين نحو ممارسات تحسين وصيانة الار اضى الزر اعية، نم إعداد

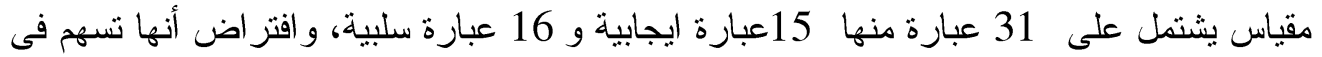
قياس اتجاه الزر اع نحو ممارسات تحسين وصيانة الأر اضى الزر اعية، وتم عرض عبار ات المقياس المبئية على عشرة محكمين كل على حده، وهم جميعا اساتذة متخصصين فى المجال، وقد طلب من

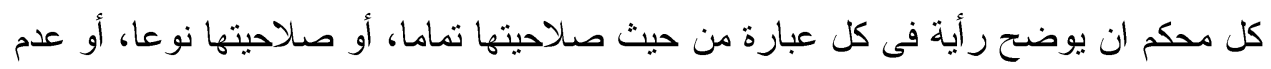

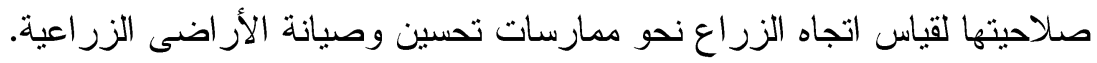
هذا وقد نم الاختيار النهائى للعبارات لما اقره ثمانية من المحكمين على الأقل بصلاحيتها تماما، وعلى ذلك تم حذف ست من العبارات، و أقتصر المقياس على 25عبارة .

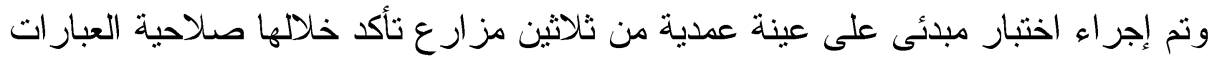

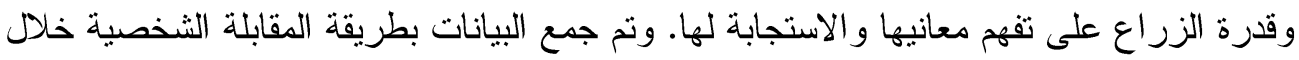
شهرى مايو ويونيه 2012م. وتم ترميز البيانات وقد أمكن تحقق الاتساق الداخلى لمقياس الاتجاهات

نحو تحسين وصيانة الأر اضى الزر اعية بحساب معاملات الارتباط بين العبارة و الدرجة الكلية

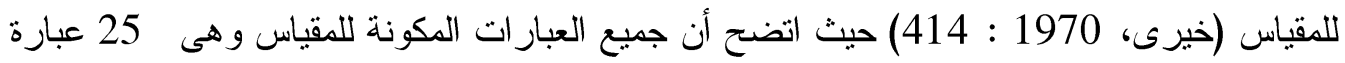
جميعها معنوية عند المستوى الاحتمالى 0.01 و نراوحت قيم معاملات الارتباط بين

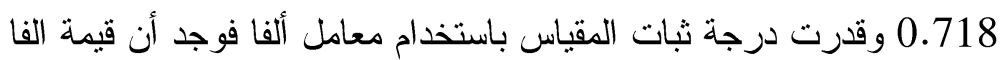
المحسوبة 0.81 و هى قيمة مرتفعه تدل على ثبات المقياس، وتؤكد نتائج الثبات و الصدق التى أمكن

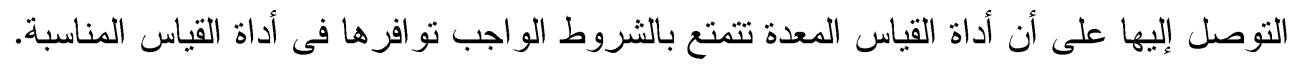
وبعد الانتهاء من التقنين تم صياغة المقياس فى صورته النهائية وطلب من المبحوث إبداء رأيه فى إنى

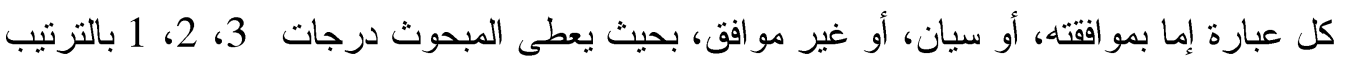

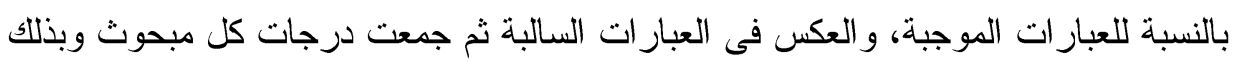
تر اوحت درجات المبحوثين ما بين( 25-75) درجة، ثم قسم المبحوثين وفقاً لدرجات اتجاهاتهم نحو 
ممارسات تحسين وصيانة الأر اضى الزر اعية إلى ثلاث فئات هى: فئة الاتجاه السلبى ونتر اوح ما

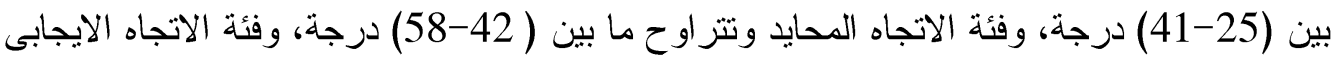

$$
\text { وتتر اوح ما بين (59-75) درجة. }
$$

ب - قياس المتغيرات المستقلة التى تضمنها البحث كما يلى بلى بلى I -السن: ونم قياسه بسؤ ال المبحوث عن سنة وقت جمع البيانات لاقرب سنة ميلادية.

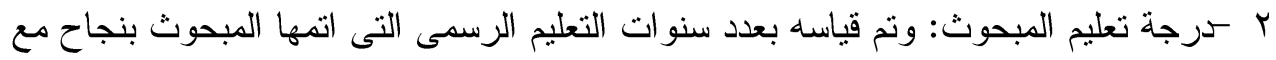
اعطاء الامى صفر ، و الذى يقر أ ويكتب أربع درجات. r -عدد سنوات الخبرة فى الزراعة: وهو متغير كمى تم قياسه بعدد سنوات اتشتغال المبحوث فى وبى الزر اعة وقت إجر اء البحث.

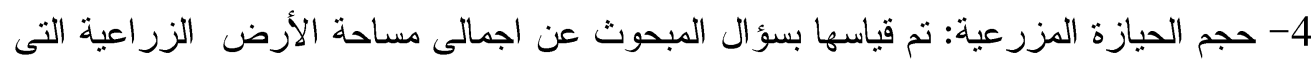
يحوزها المبحوث بالقير اط سو اء ملك أو إيجار . ه -حجم الحيازة الحيو انية: وقد تم حساب الحيازة الحيو انية بجمع اجمالى حيازة الجاموس و الأبقار و الإبل و الماعز و الأغنام، حيث أعطيت الأوزان المرجحة كالتالى: الجاموس سنئ سنتين فأكثر

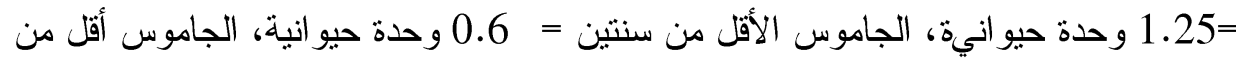
سنه=0.3 وحدة حيو انية، الأبقار سنتين فأكثر = وحدة حيو انية، الأبقار أقل من سنتين = 0.5 وحدة حيو انية، الأبقار أقل من سنه =0.2 وحدة حيو انية، الأغنام = 0.1 وحدة حيو انية، الماعز الإبهار 0.7 0.7 حدة حيو انية، الإبل = 0.75وحدة حيو انية.(خليفة، ونخال، 2005: 1021-1025)

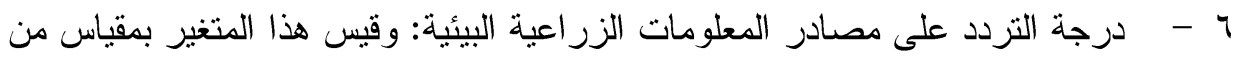
عشرة بنود تتعلق بمصادر حصول المبحوث على المعلومات الخاصة بالبيئة وصيانة وتحسين

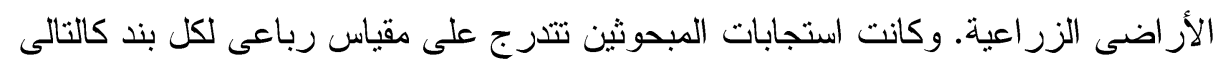

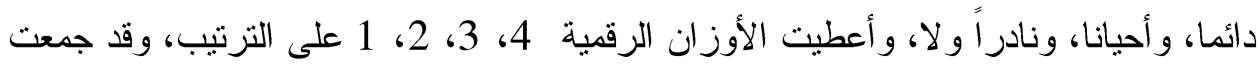

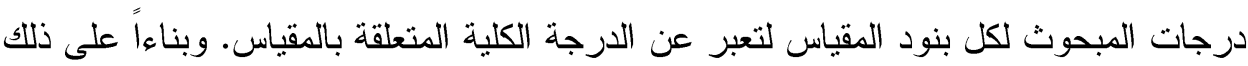

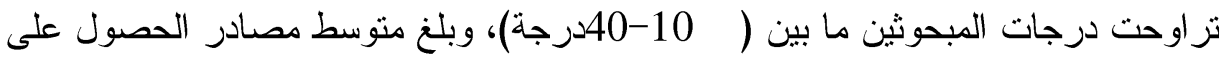

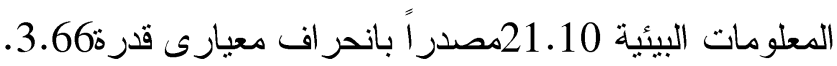
7- الدخل الأسرى الشهرى: يعبر عن اجمالى دخل الأسرة الثهرى بالجنية من المصادر المختلفة. 8- درجة تو افر التسيلات المجتمعية: وتم قياس هذا المتغير بمقياس مكون من خمسة بنود تتعلق

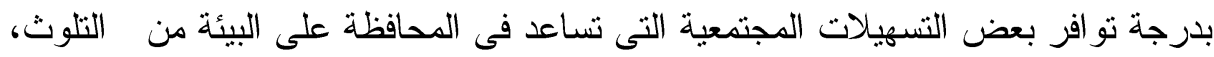

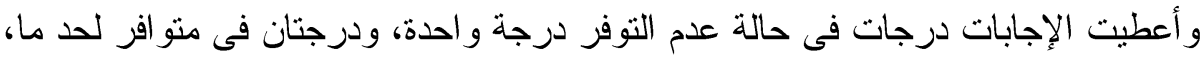

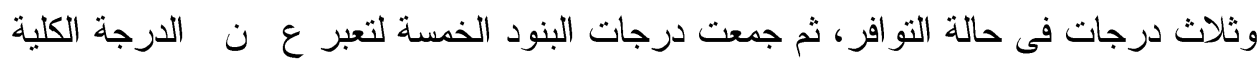
للمقياس. وبناءاً على ذلك نراوحت درجات المبحوثين ما بين( 5 5-15 درجة)، وبلغ منوسط تو افر التسهيلات المجتمعية 10.18درجة بانحر اف معيارى قدره 2.7. 9- درجة الانتماء للمجتمع المحلى: وقد قيس هذا المتغير بمقياس مكون من تسعة بنود تتعلق بمدى بلهي

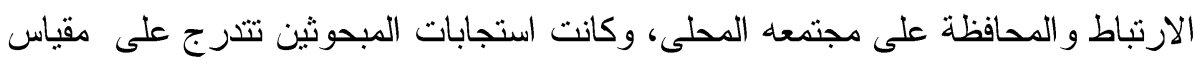


ثلاثى لكل بند هى مو افق، وسيان، وغير مو افق، و أعطيت الأوزان الرقمية 3، 2، 1 على

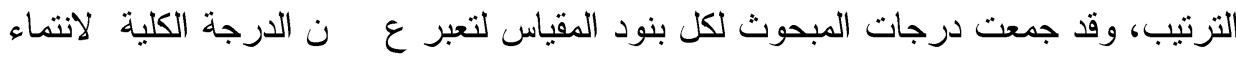

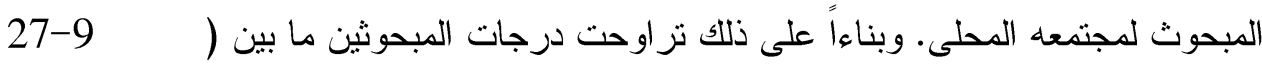

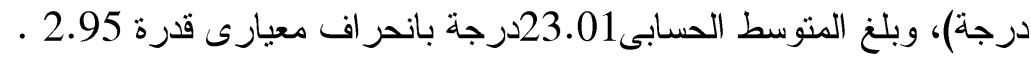

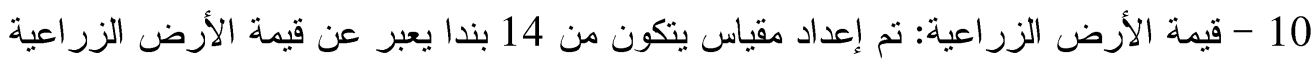

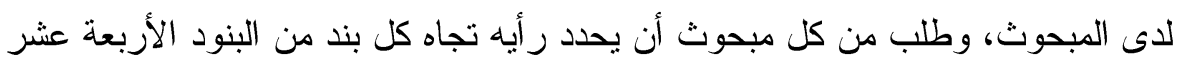

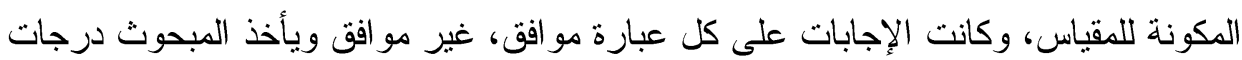

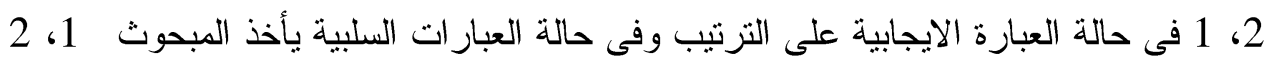
على التزتيب. وبحساب معامل ثبات الفا لبنود المقياس وجد أن معامل الثبات

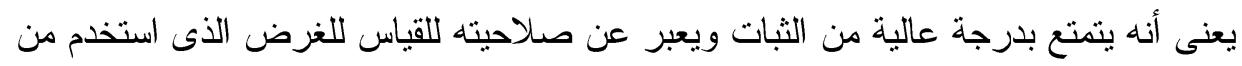

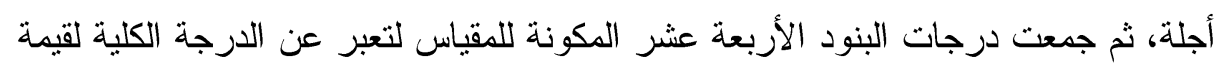

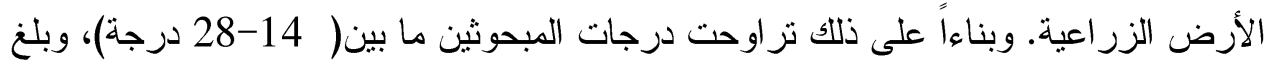
متوسط قيمة الأرض الزراعية 24.17درجة بانحر اف معيارى قدرة 2.47. 11- درجة المعرفة بالأضر ار الناجمة عن ممارسات تلوث البيئة: لتحديد درجة معرفة المزر اعين المبحوثين بالإضرار الناجمة عن ممارسات تلوث البيئة نم استخدام مقياس يتضمن عشرة بنود

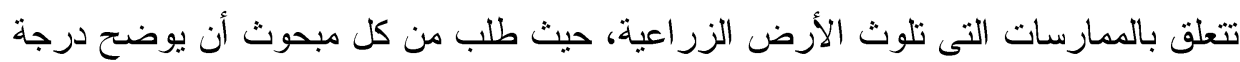
خطورة كل ممارسة على البيئة، وكانت استجابات المبحوثين تتدرج على مقياس رباعى لكل ممارسة هى خطر و اضح، وخطر ممكن، وخطر بسيط و لا يكون خطر ، وأعطيت تلاك

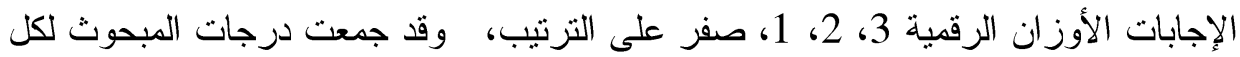

بنود لمقياس لتعبر عن الدرجة الكلية للمعرفة بالإضرار الناجمة عن ممارسات تلوث البيئة.

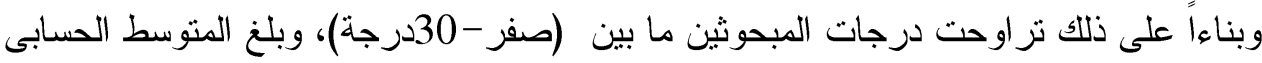

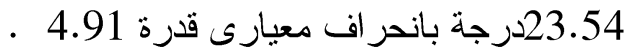
رابعاً: أدوات التحليل الاحصائى

لتحليل بيانات هذا البحث إحصائيا تم استخدام اختبار تحليل التباين، ومعامل الارتباط

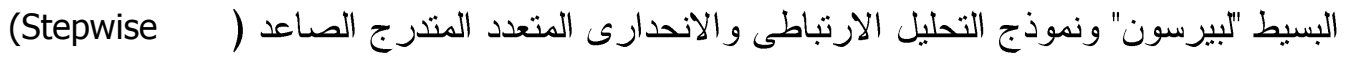
ومعامل إلفا، كما تم استخدام العرض الجدولى بالتكر ار و النسب المئوية لعرض بعض ولن بيانات هذا 
عبار ات قياس اتجاه الزر اع نحو ممارسات تحسين وصيانة الأر اضى الزر اعية فى بعض قرى محافظات البحيرة و الغربية وكفر الثيخ

\begin{tabular}{|c|c|c|c|c|}
\hline غير & سيان & 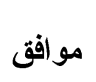 & \multicolumn{2}{|l|}{ 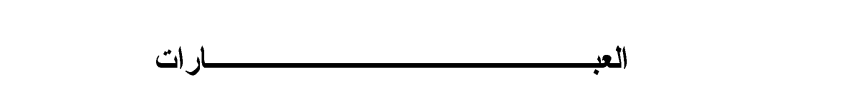 } \\
\hline & & & الحرث و الخدمة الجيدة قبل زراعة كل محصول مفيدة للأرض. & 1 \\
\hline & & & أفضل ترك الأرض الزراعية فترة كافية للتهوية والتثميس. & 2 \\
\hline & & & أحب وضع السماد الكيماوى بالكميات الموصى بها. & 3 \\
\hline & & & تحسين حالة الصرف الزراعى مشمه للأرض. & 4 \\
\hline & & & أفضل زراعة المحاصيل البقولية مثل الفول والبرسيم لتحسين حالة & 5 \\
\hline & & & الناس بتفضل النقاوة البدوية للحشائش عن رش المبيدات. & 6 \\
\hline & & & إتباع الدورة الزراعية للحفاظ على خصوبة الأرض الزراعية. & 7 \\
\hline & & & البناء على الأرض الزراعية أهم من زراعتها. & 8 \\
\hline & & & وضع السماد البلاى للأرض الزراعية ملهوش فائدة. & 9 \\
\hline & & & استخدام مياه الصرف فى رى الارضى الززراعية بيضر ها. & 10 \\
\hline & & & أحسن حاجة أن الواحد ما يجرفش أرضة. & 11 \\
\hline & & & اروى الأرض الزراعية عذد الحاجة فقط. & 12 \\
\hline & & & يزعجنى رش المبيدات الكيماوية على الفاضى والمليان. & 13 \\
\hline & & & زيادة عدد بناء مزارع الدواجن على الأرض الزراعية. & 14 \\
\hline & & & يحزننى زيادة البناء على الأرض الزراعية بعد الثورة. & 15 \\
\hline & & & أكون سعيداً لما بكون هناك إجراءات حازمة للتعديات الزراعية. & 16 \\
\hline & & & تجريف الأرض الزراعية بيقو بها ويحسنها. & 17 \\
\hline & & & كثرة رش المبيدات فى الأرض الزراعية بيطهرها. & 18 \\
\hline & & & أحب أسوى الأرض بالليزر. & 19 \\
\hline & & & يعجبنى المزارع اللى يستخام كيماوى كثير فى الأرض لزيادة الإتتاج. & 20 \\
\hline & & & رمى الحيوانات الميتة فى الترع شى ع عادى. & 21 \\
\hline & & & رمى عبوات المبيدات فى الترع بيطهر ميتها & 22 \\
\hline & & & صرف مية الزراعة فى الترع ملهوش أضرار. & 23 \\
\hline & & & رمى علب المبيدات الفارغة فى التربة الزراعية ملهوش أضرار. & 24 \\
\hline & & & يزعجنى رى الأرض بالغمر. & 25 \\
\hline
\end{tabular}




\section{النتائج ومناقشتها}

أو لا: مستوى اتجاه الزراع المبحوثين نحو ممارسات تحسين وصيانة الار اضى الزر اعية بالقرى

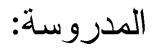

جدول (1) توزيع المبحوثين وفقا لاتجاهاتهم نحو ممارسات

\begin{tabular}{|c|c|c|}
\hline \multicolumn{3}{|c|}{ تحسين وصيانة الأر اضى الزر اعية. } \\
\hline (\% ) النسبة المئوية & 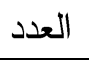 & فئات الاتجاه \\
\hline 23.00 & 69 & سلبى (25-41) درجة \\
\hline 29.33 & 88 & محايد (42-58) درجة \\
\hline 47.67 & 143 & ايجابى (59-75) درجة \\
\hline 100 & 300 & 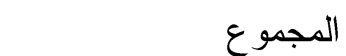 \\
\hline
\end{tabular}

يتبين من النتائج بالجدول رقم ( 1) أن ما يقرب من ربع المبحوثين 23\% يقعون فى فئة الاتجاه

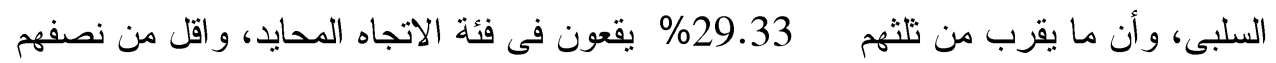

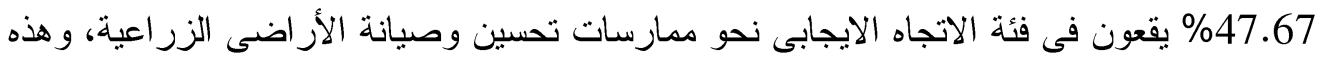

النسبة معقولة الى حد ما ولكن ما زال هناك بعض السلبيات التى تعون التعوق من تغير اتجاهات هؤ لاء

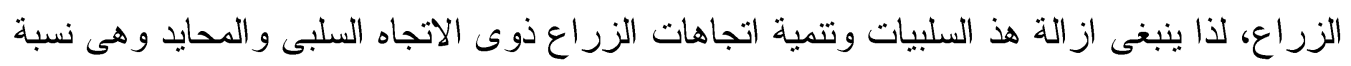

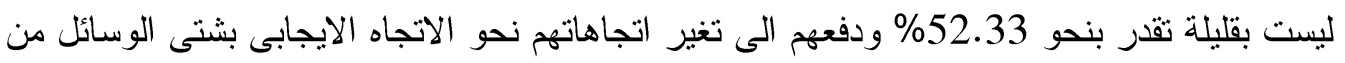
خلال اظهار سلبيات واخطار واضرار عدم تحسين وصيانة الأر اضى الزر اعية على الاجيال المقبلة

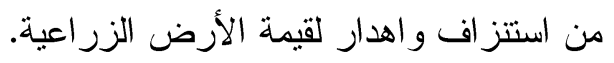

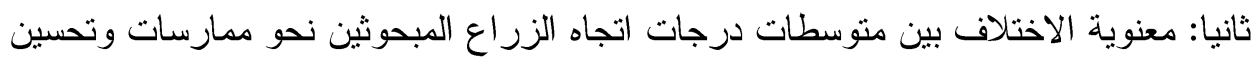

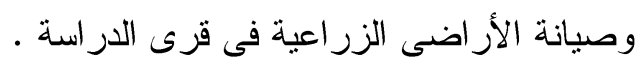

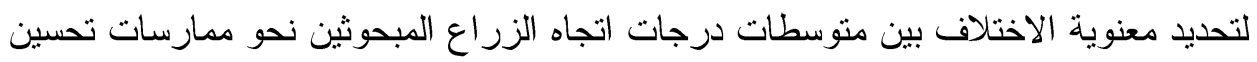

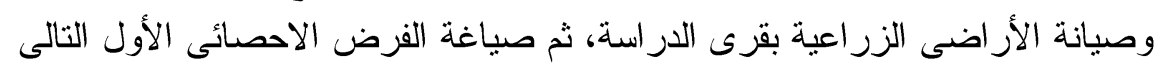

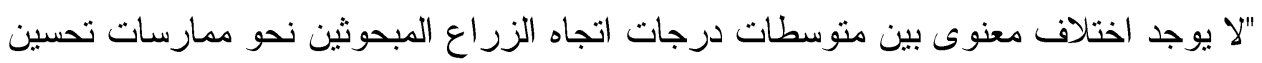

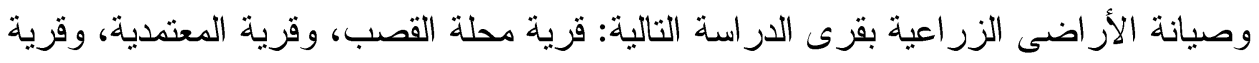

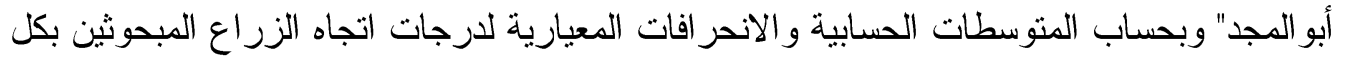
قرية من القرى الثثلاثة وباختبار معنوية الفروق بينهم باستخدام اختبار (ف) أنثارت النتائج

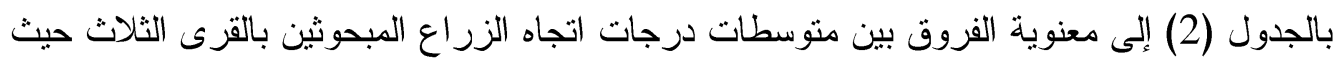
بلغت قيمة (ف) المحسوبة 3.59 وهى أكبر من مثيلتها الجدولية (3.27) عند مسنوى معنوى دئو 0.05

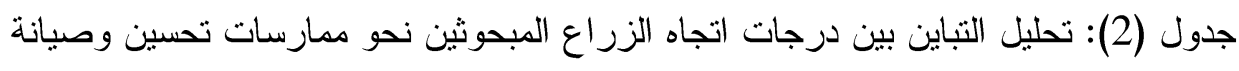

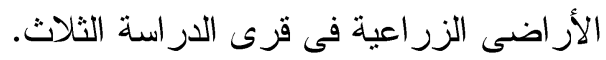

\begin{tabular}{|c|c|c|}
\hline قيمة (ف) المحسوبة & متوسطات درجات الاتجاه & الزر اع المبحوثين \\
\hline \multirow{3}{*}{3.590} & 61.140 & قرية محلة القصب (كفر الثيخ) \\
\hline & 64.230 & قرية ابو المجد (البحيرة) \\
\hline & 60.817 & قرية المعتمدية (الغربية) \\
\hline
\end{tabular}

قيمة (ف) الجدولية عند مستوى معنوى 0.05 ودرجات حرية 297.27

قيمة (ف) الجدولية عند مستوى معنوى 0.01 ودرجات حرية 297.257 
وبحساب الفروق بين متوسطات القرى الثلاث فقد أنشارت النتائج الواردة بجدول ( 3) إلى وجود فروقاً بينها بلغت قيمتها بين قريتى ابو المجد و المعتمدية 3.9 درجة، وبين قريتى ابو المجد ومحلة القصب 3.09 درجة، و أيضاً الفروق بين قريتى محلة القصب و المعتمدية فقد بلغ 323. 0 مدرجة.

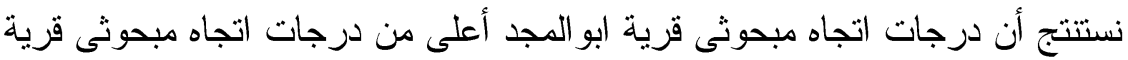

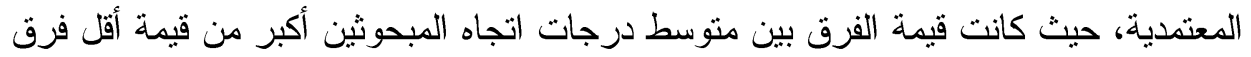

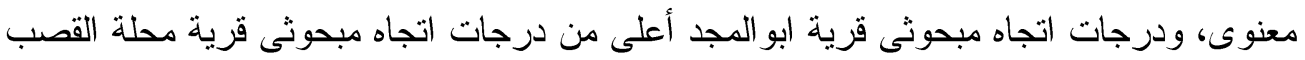

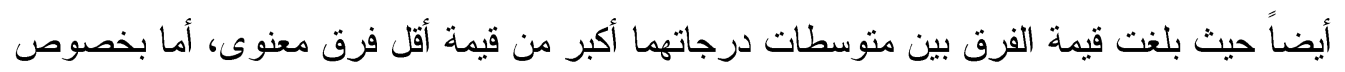

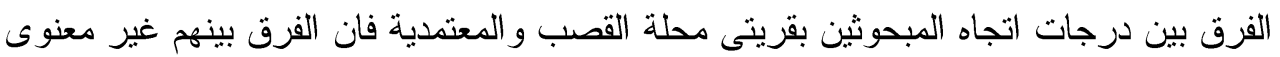

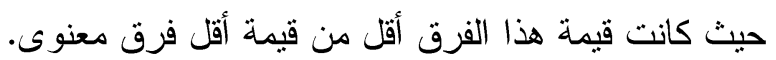
وبحساب أقل فرق معنوى بين القرى الثلاثة وجد أن أقل فرق معنوى يساوى فئل فئل 2.352 ويوضح جدول (3) أقل فرق معنوى بين القرى الثناثة .

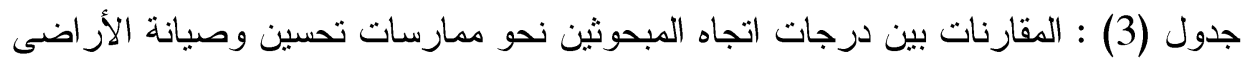

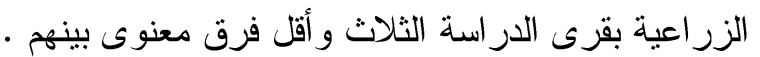

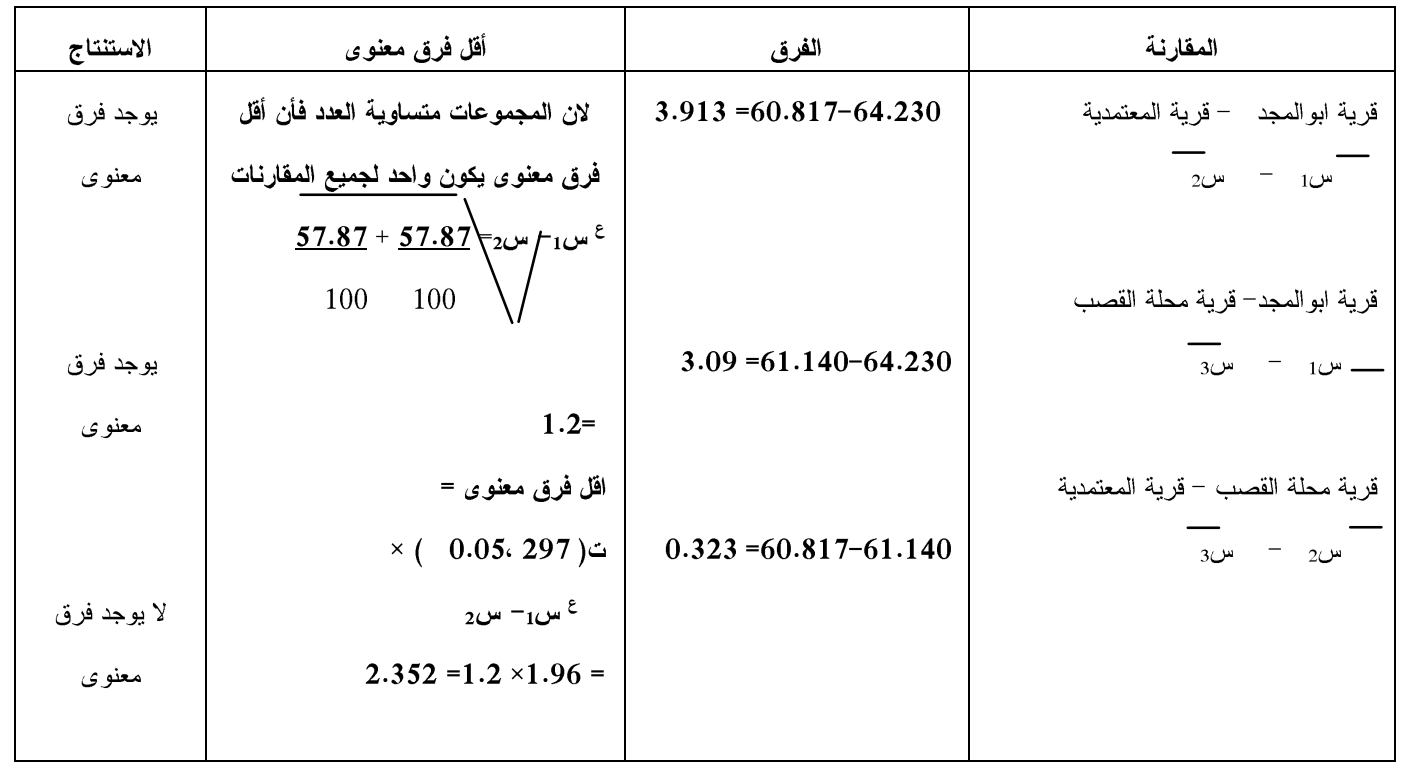

وبناء على ذلك يمكن رفض الفرض الاحصائى الأول و لا نستطيع رفض الفرض البديل فيما يتعلق بالفرق بين قرية ابو المجد وقرية المعتمدية، و الفرق بين قرية ابو المجد وقرية محلة القصب فيما لاولاه

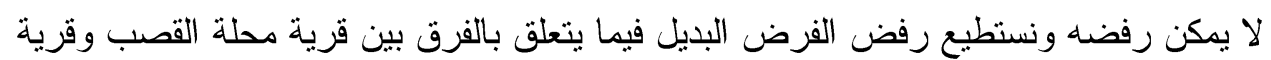
المعتمدية. ثالثاً: العلاقة بين كل من المتغيرات المستقلة المدروسة واتجاه الزراع المبحوثين نحو ممارسات

$$
\text { تحسين وصيانة الأر اضى الزر اعية: }
$$

للتعرف على العلاقة بين درجات اتجاه الزراع المبحوثين نحو ممارسات تحسين وصيانة الأراضى اضلى إنى الزر اعية تم صياغة الفرض الاحصائى الثانى"لا توجد علاقة ارتباطيه معنوية بين درجات اتجاه 
الزر اع المبحوثين نحو ممارسات تحسين وصيانة الأراضى الزر اعية وبين كل من المتغيرات

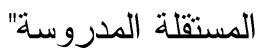

و لاختبار هذا الفرض حسبت قيم معامل الارتباط البسيط حيث أوضحت النتائج الواردة فى جدول (4) أن قيم معاملات الارتباط البسيط بين درجات اتجاه الزر اع المبحوثين نحو ممارسات تحسين وصيانة

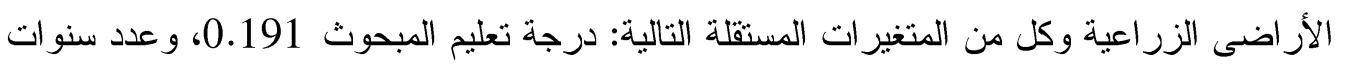

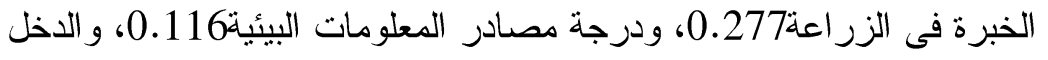

الأسرى الثهرى 0.207، ودرجة تو افر التسهيلات المجتمعية 0.444، ودرجة الانتماء للمجتمع المحلى0.526، وقيمة الأرض الزراعية 0.1910، ودرجة المعرفة بالاضر ار الناجمة عن ممارسات

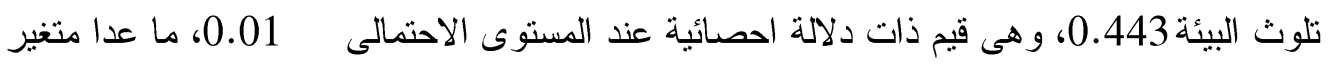

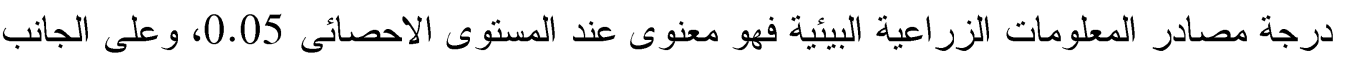

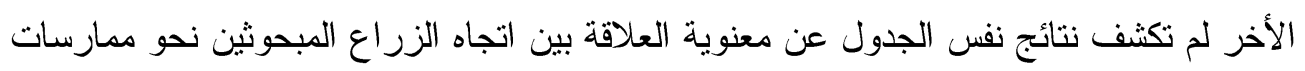

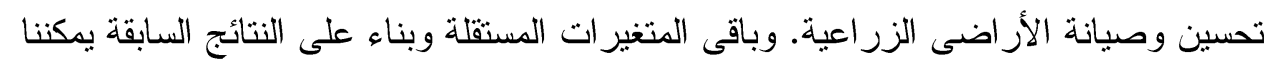

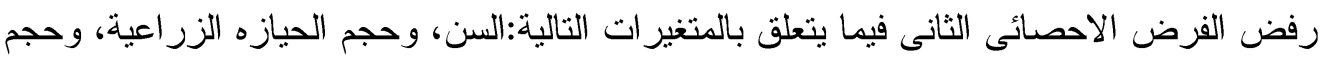
الحيازه الحيو انية ولا نسنطيع رفض الفرض البديل فيما يتعلق بالمتغيرات التالية: درجة تعليم

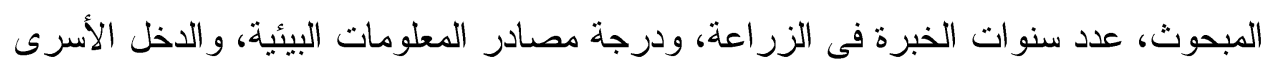

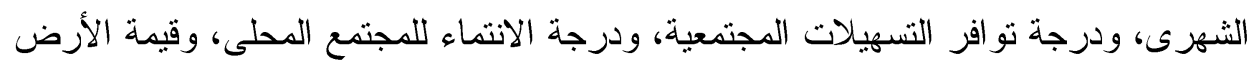

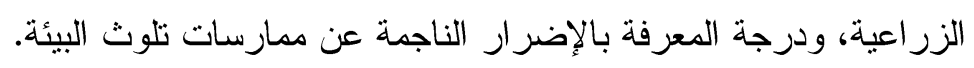

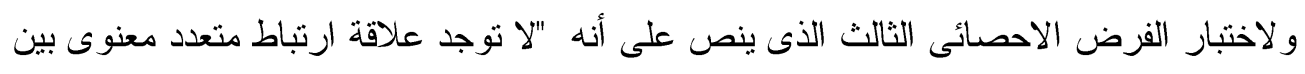

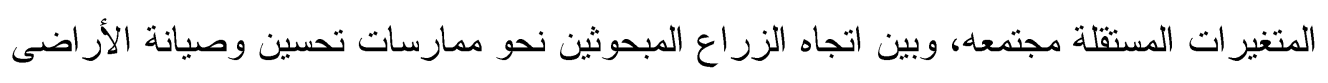
الزر اعية" أنشارت النتائج عن وجود علاقة ارتباطيه معنوية بين درجات اتجاه الزراع المبحوثين نحو

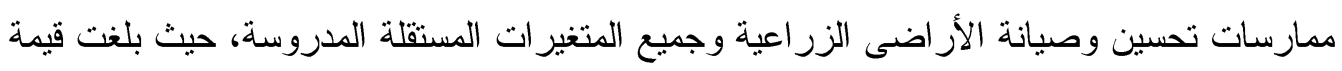
(ف) 28.23 و هى قيمة ذات دلالة احصائية عند المستوى الاحتمالى 0.01 وبناء على النتائج السابقة يمكن رفض الفرض الاحصائى الثالث و عليه يمكن قبول الفرض البديل.

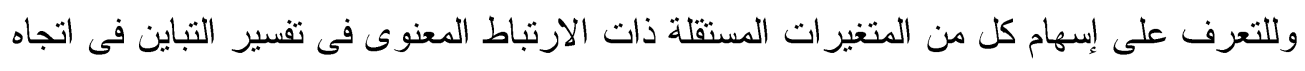

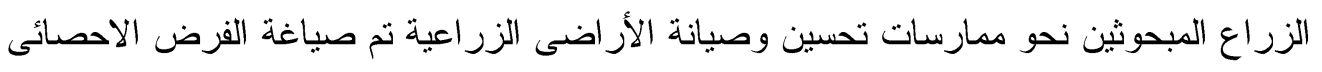

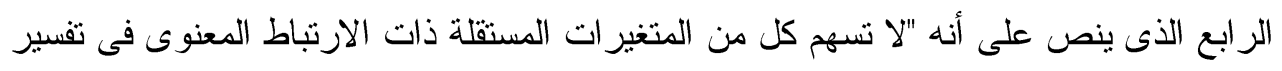

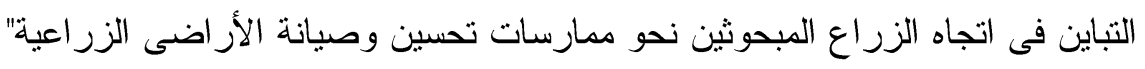

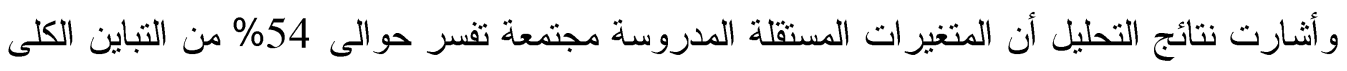

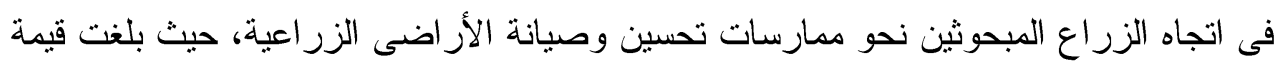

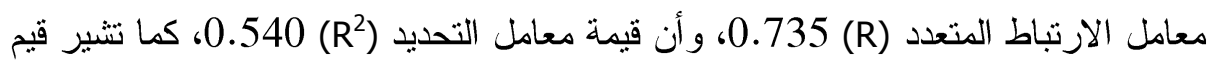

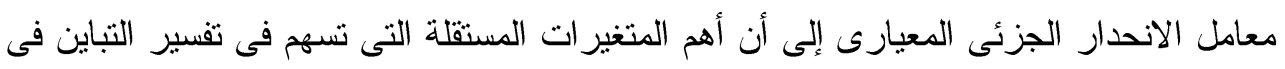


اتجاه الزراع المبحوثين نحو ممارسات تحسين وصيانة الأراضى الزر اعية هى درجة تعليم المبحوث

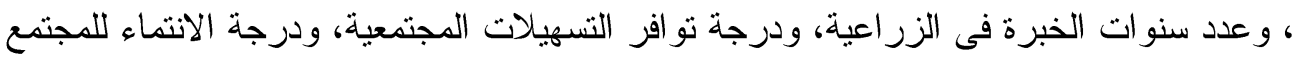

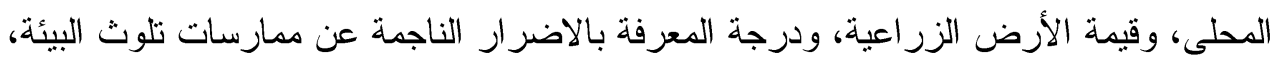
وبناء على النتائج السابقة يمكن رفض الفرض الإحصائى الرابع فيما ينعلق بالمتغيرات التالية وهى:

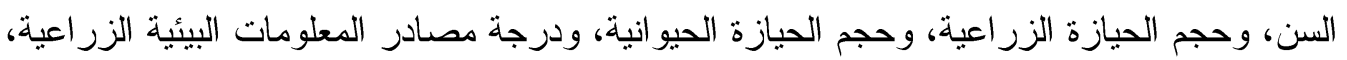
و الدخل الأسرى الثهرى ولا نستطيع رفض الفرض البديل فيما يتعلق بالمتغيرات التالية وهى: درجة ورجة

تعليم المبحوث، وعدد سنوات الخبرة فى الزر اعة، ودرجة تو افر التسهيلات المجتمعية، ودرجة الانتماء للمجتمع المحلى، وقيمة الأرض الزراعية، ودرجة المعرفة بالاضرار الناجمة عن ممارسات تلوث البيئة. جدول (4) : نتائج تحليل الارتباط البسيط والانحدار الخطى المتعدد للمتغيرات المستقلة بين درجات

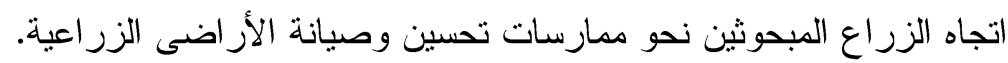

\begin{tabular}{|c|c|c|c|}
\hline قيمة (ت) & قيمة معامل انحدار & قاليمة معامل & المتغيرات المستقلة \\
\hline $1.043^{-}$ & $0.074-$ & 0.021 & 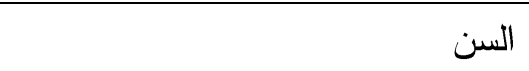 \\
\hline$* * 4.910$ & $* 0.237$ & $* * 0.191$ & درجة تعليم المبحوث \\
\hline$* * 4.117$ & $* * 0.307$ & $* * 0.277$ & عدد سنو ات الخبرة فى الزراعة \\
\hline 0.004 & 0.056 & 0.070 & حجم الحيازة الزر اعية \\
\hline $0.047-$ & $0.018-$ & $0.028-$ & حجم الحيازة الحيو انية \\
\hline 1.044 & 0.048 & *0.116 & درجة مصسادر المعلومات الزراعية \\
\hline 1.520 & 0.075 & $* * 0.207$ & البيئية \\
\hline$* * 6.899$ & $* * 0.302$ & $* * 0.444$ & الدخل الأسرى الثهرى \\
\hline$* * 4.594$ & $* * 0.229$ & $* * 0.526$ & درجة تو افر التسهيلات المجتمعية \\
\hline$* 2.243$ & $* 0.194$ & $* * 0.191$ & درجة الانتماء للمجتمع المحلى \\
\hline$* * 4.522$ & $* * 0.229$ & $* * 0.443$ & قيمة الأرض الزر اعية \\
\hline & & & درجة المعرفة بالاضر ار الناجمة عن \\
\hline & & & ممارسات تلوث البيئة \\
\hline \multicolumn{3}{|c|}{ * معنوى عند المستوى الاحتمالى 0.05} & $0.735=0$ = معامل الارتباط المتعدد (R ) \\
\hline \multirow{2}{*}{\multicolumn{3}{|c|}{ ** * معنوى عند مستوى الاحتمالى 0.01}} & $0.540=\left(R^{2}\right)$ معامل التحديد \\
\hline & & & قيمة (ف) = 28.23" \\
\hline
\end{tabular}

وفى محاولة للوقوف على اكثر المتغيرات المستقلة تأثيراً على المتغير التابع نم استخدام الانحدار التدرجى الصاعد فأسفر التحليل عن معادلة انحدار خطى تتضمن ستة متغيرات هى: درجة الانتماء 
للمجتمع المحلى، ودرجة تو افر التسهيلات المجتمعية، ودرجة المعرفة بالإضرار الناجمة عن تلوث

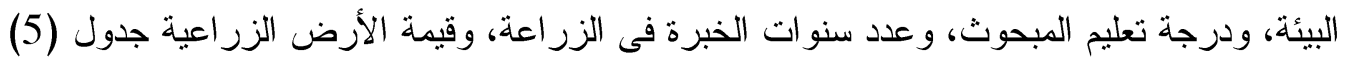

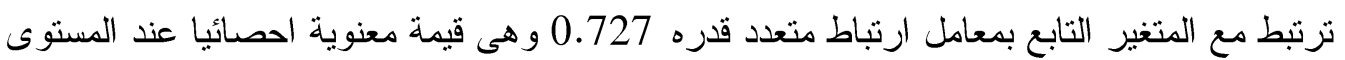
الاحتمالى 0.01 ، و هكذا ينبغى استتناج أنه توجد علاقة ارتباطيه معنوية بين هذه المتغير ات مجتمعهد و المتغير التابع كما بلغت قيمة معامل التحديد 0.528. جدول (5): نموذج مختصر للعلاقة بين المتغيرات المستقلة واتجاه الزراع المبحوثين نحو ممارسات تحسين وصيانة الأر اضى الزر اعية.

\begin{tabular}{|c|c|c|c|c|}
\hline قيمة (ت) & 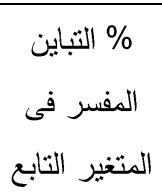 & $\begin{array}{c}\text { \% التنز اكمية } \\
\text { اللتبنين } \\
\text { المفسر }\end{array}$ & معامل الانحدار & المتغيرات الداخلة فى المعادلة \\
\hline$* * 5.237$ & 0.277 & 0.277 & 0.255 & درجة الانتماء للمجتمع المحلى \\
\hline$* * 7.373$ & 0.119 & 0.396 & 0.306 & درجة تو افر التسهيلات المجتمعية \\
\hline **5.303 & 0.550 & 0.451 & 0.252 & درجة المعرفة بالاضر ار الناجمة عن تلوث \\
\hline$* * 4.301$ & 0.021 & 0.072 & 0.263 & البيئة \\
\hline$* * 5.047$ & 0.048 & 0.520 & 0.245 & درجة تعليم المبحوث \\
\hline$* * 2.186$ & 0.008 & 0.528 & 0.091 & قيمة الارض سنو الزبرات الخبرة فى الزر اعة \\
\hline
\end{tabular}

0.05 * معنوى عند المستوى الاحتمالى *

0.010
$0.727=0$ = معامل الارتباط المتعدد (R)

$0.528=\left(R^{2}\right)$ معامل التحديد

"

ومعنى ذلك أن هذه المتغيرات الستة وحدها تفسر 52.8\% من التباين فى المتغير التابع، ويرجع 27.7\% الى متغير درجة الانتماء للمجتمع المحلى، ويضيف متغير درجة تو افر التسهيلات المجتمعية 11.9\% أخرى، كما يضيف متغير درجة المعرفة بالاضر ار الناجمة عن ممارسات تلوث

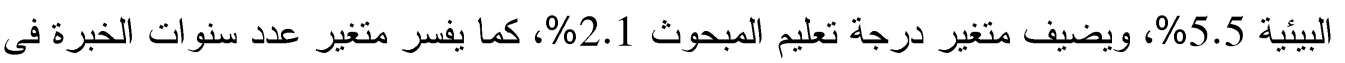

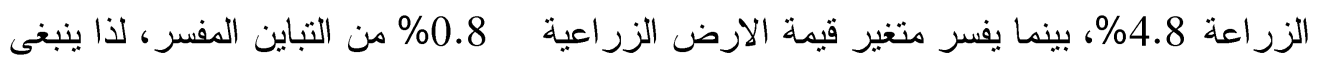

إعطاء اهنمام أكبر لرفع درجة الانتماء للمجتع المحلى و العمل على زيادة توفير التسهيلات

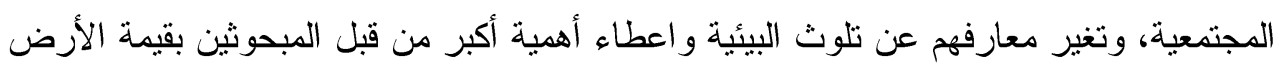

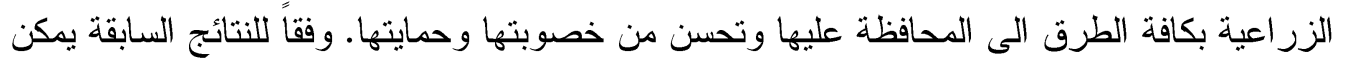
رفض الفرض الاحصائى الرابع ولا نستطيع رفض الفرض البديل.

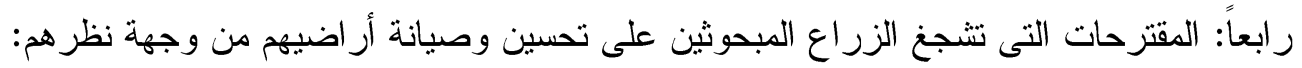

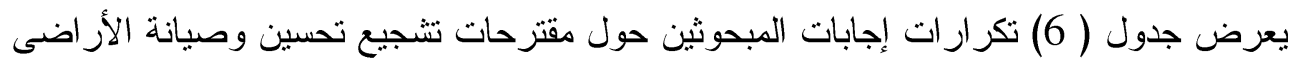

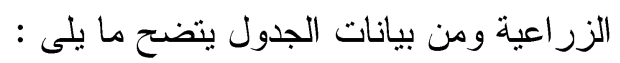

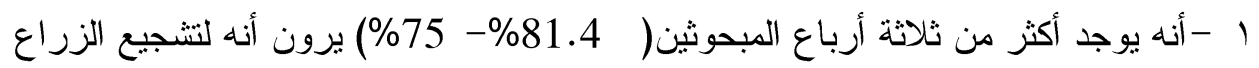

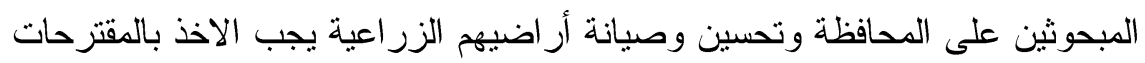


التالية : الاهتمام بتدريس المقررات البيئية فى جميع مراحل التعليم ومنها المحافظة على الأرض الزراعية ،وتوعية الريفي ن بأهمية الأرض الزر اعية وقيمتها، وتثنديد العقوبة لهربة

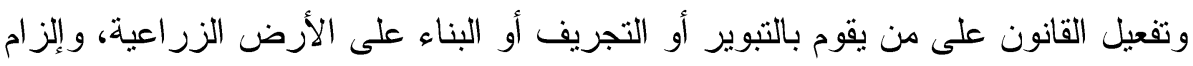

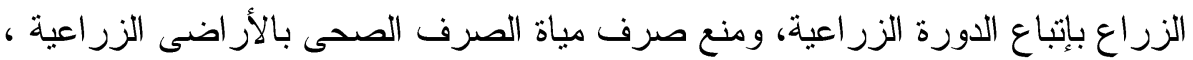
وتتشيع الزراع على القيام بالزر اعة العضوية .

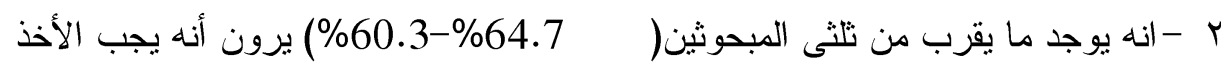
بالمقترحات التالية لتحسين وصيانة الأرض الزر اعية وهى: تعريف الزراع بلى بإخطار تلوث

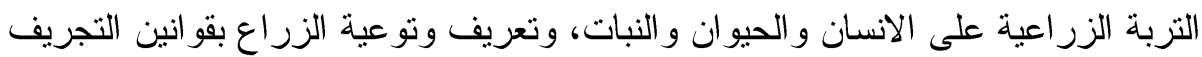
وخطر تبوير الأرض الزر اعية والبناء عليها، وتوعية الزراع بقانون حماية الموارد المائية

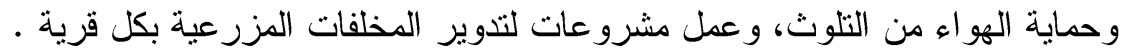
ب - أنه يوجد أقل من نصف المبحوثين( 49.68-45.51\%) يرون أن الاخذ بالمقترحين

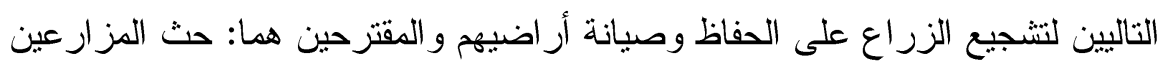

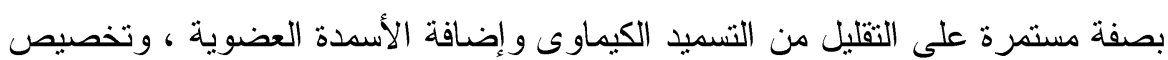
أماكن معينة لكل قرية لالقاء المخلفات المنزلية و المزرعية. جدول (6): توزيع إجابات الزراع المبحوثين حول المقترحات التى تدفعهم نحو تحسين وصيانة

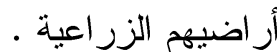

\begin{tabular}{|c|c|c|c|}
\hline \multirow{3}{*}{$\begin{array}{c}\% \\
81.41\end{array}$} & 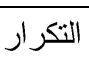 & المقتــــــــرح & م \\
\hline & \multirow[t]{2}{*}{254} & الاهتمام بترريس المقرر ات البيئية فى جميع مر احل التعليم ومنها المحافظة على & \multirow[t]{2}{*}{1} \\
\hline & & الارض الزر اعية & \\
\hline 77.56 & 242 & تو عية الريفيين بأهمية الارض الزر اعية وقيمتها & 2 \\
\hline \multirow[t]{2}{*}{75.96} & \multirow[t]{2}{*}{237} & تتنديد العقوبة وتفعيل القانون على من يقوم بالتبوير أو التجريف او البناء على & \multirow[t]{2}{*}{3} \\
\hline & & الارض الزراعبة & \\
\hline 75.32 & 235 & الزام الزر اع بإتباع الدورة الزر اعية & 4 \\
\hline 75.32 & 235 & منع صرف مياة الصرف الصحى بالمصارف الزر اعية & 5 \\
\hline 75.0 & 234 & تتجيع الزراع على القيام بالزر اعة العضوية & 6 \\
\hline 64.7 & 194 & تعريف الزراع بإخطار تلوث النزبة الزر اعية على الانسان و الحيوان و النبات & 7 \\
\hline 64.7 & 194 & تعريف وتو عية الزر اع بقو انين التجريف وخطر نبوير الارض الزر اعية و البناء عليها & 8 \\
\hline 62.7 & 188 & تو عية الزراع بقانون حماية الموارد المائية وحماية الهو اء من التلوث & 9 \\
\hline 60.3 & 181 & عمل مشروعات لتدوير المخلفات المزرعية بكل قرية & 10 \\
\hline 49.68 & 155 & العض المز ارعبن بصفة مستمرة على التقليل من التسميد الكيماوى واضافة الاسمدة & 11 \\
\hline 45.51 & 142 & تخصيص اماكن معينة لكل قرية لالقاء المخلفات المنزلية & 12 \\
\hline
\end{tabular}

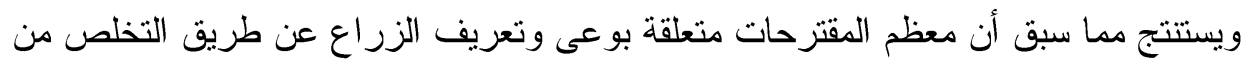
المخلفات المزرعبة و المنزلية، وكذلك بقو انين التجريف ،وكذلك توعيته بحماية الموارد المائية، وتوعيتهم بأهمية الأرض الزر اعية وقيمتها بالنسبة لهم وللأجيال المقلبة . 


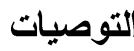

بناء على نتائج البحث بمكن التوصية بما يلى: 1 - نتمية مفاهيم الزراع بالاتجاهات الايجابية عن الحفاظ على البيئة الزر اعية وتلوثها لئها

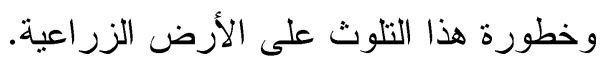

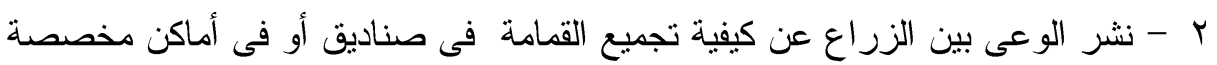

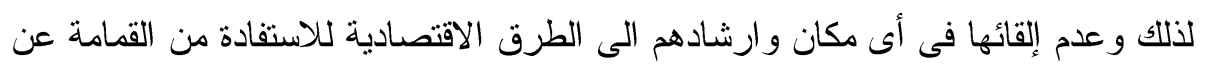
طريق تدويرها. ب - توعية الزراع إلى عدم استخدام مياة الصرف الصحى فى رى الأرض إلا بعد معالجتها.

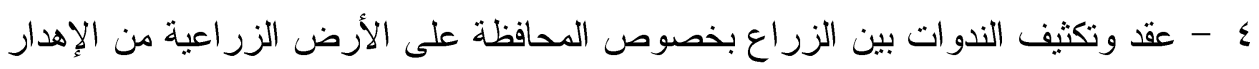

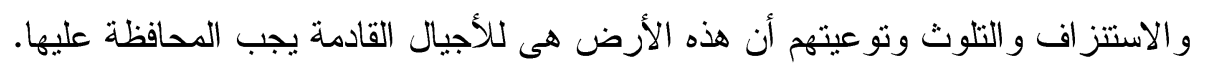

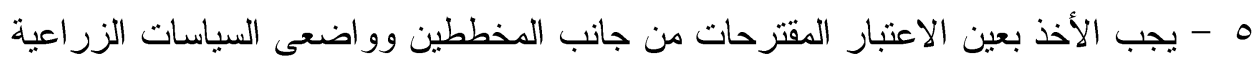

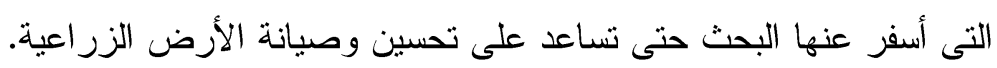

\section{المر اجع}

1. إبر اهيم، سكينة محمد ( 1994): در اسة مقارنة لاثر بعض وسائل الإتصال المستخدمة فى

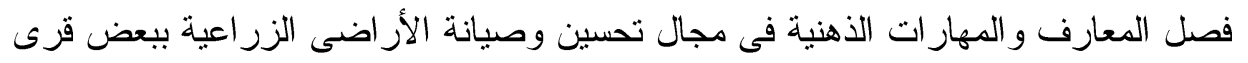
محافظة الدقلية، رسالة دكتور اه، كلية الزر اعة بكفر الثيخ، جامعة طنطا.

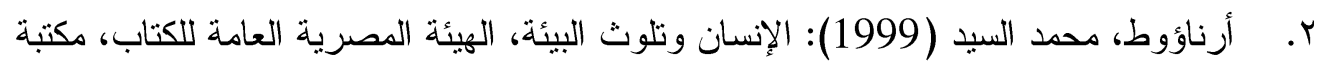
الأسرة. r. الجبالى، أبوزيد، ومصطفى حافظ ( 1990): دراسة الاحتياجات التدريبية والارشادية للزراع

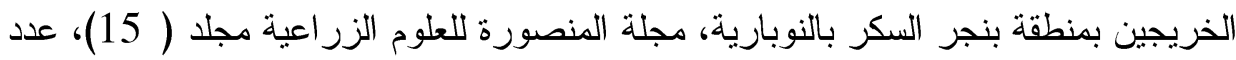

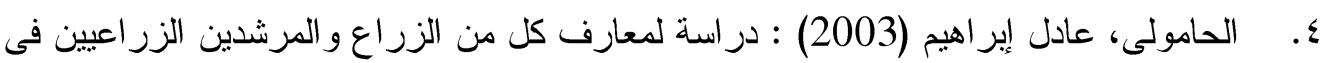

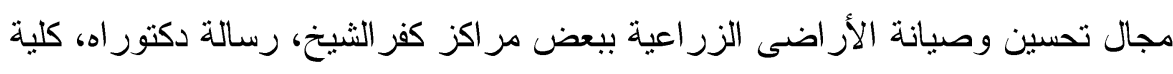

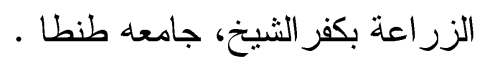
0. السيد، عزيزة عوض الله ( 1996): الاحتياجات الارشادية للريفيات بمحافظة البحيرة فى طى

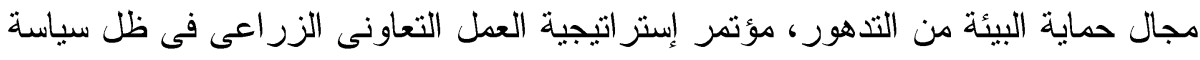

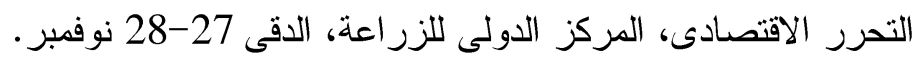

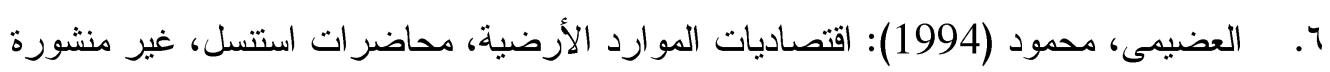
كلية الزر اعة، جامعة عين شمس.

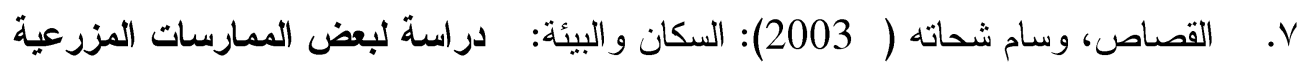
و المنزلية للسكان الريفيين عن الموارد الأرضية و المائية فى قريتين بمحافظة الثرقية، رسانة رسالة دكتور اه، كلية الزر اعة، جامعة القاهرة. 
^. الكعبارى، زينب أمين ( 2001): سلوك الريفيين المتعلق بالمحافظة على البيئة من منظور

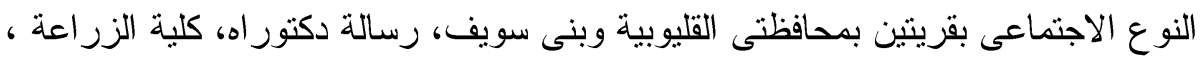

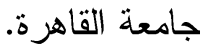
9 . المجلة الزر اعية (2000): إستر اتجية التتمية الزراعية حتى عام 2017، مؤسسة دار التعاون

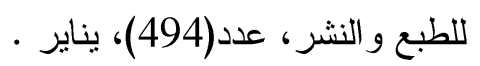
• ا. بليغ، عبد المنعم ( 1999): استصلاح وتحسين الأراضى، مكتبة المعارف الحديثة الطبعة

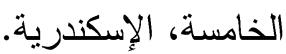
1ا. جمعه، أمل محمد محمود (2007): منطلبات دور المرأة الريفية فى إنتاج غذاء نظيف امن،

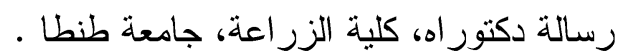

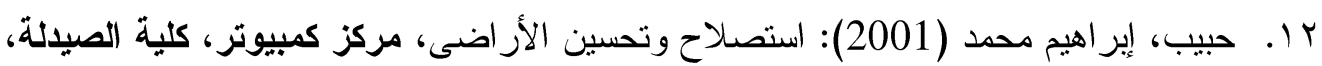
جامعة (القاهرة . با ـ حمد، محمد السيد محمد ( 1995): اتجاهات الريفيين نحو المنظمات الريفية فى محافظة

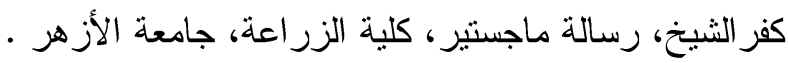

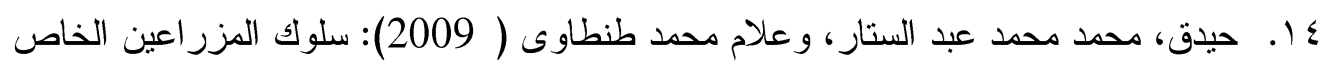
بالمحافظة على الأرض الزر اعية ومياه الرى فى محافظة كفر الثيخ، مجلة الإسكندرية للتبادل العلمى، مجلد (30)، العدد الرابع، أكتوبر - ديسمبر .

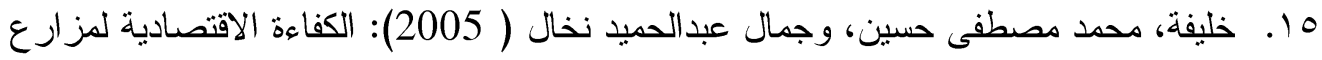

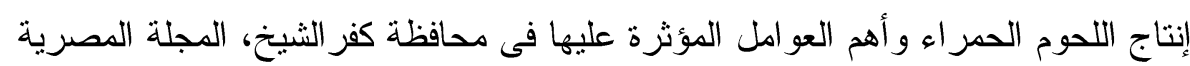
للاقتصاد الزر اعى، المجلد (15)، العدد الر ابع، ديسمبر .

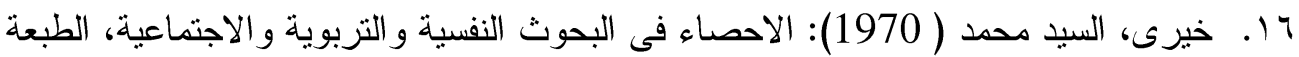
الر ابعة، دار النهضة العربية، القاهرة. V V . داود، رضا محمود(1998): تبنى وذيوع مستحدث صيانة الموارد الزر اعية بالمناطق الريفية بمحافظة المنوفية، رسالة ماجستير ، كلية الزر اعة، جامعة طنطا.

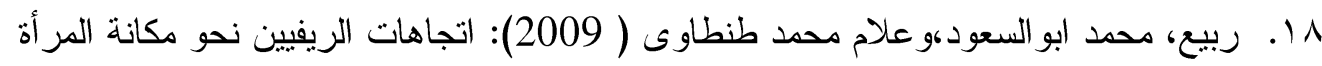
الريفية ببعض قرى محافظة الغربية، مجلة البحوث الزر اعية، جامعة كفر الثيخ، مجلد( 35)،

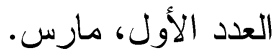

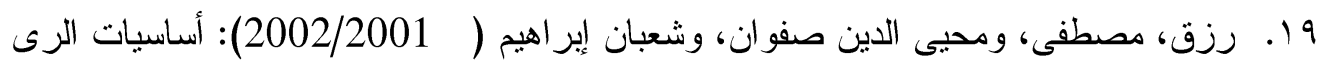

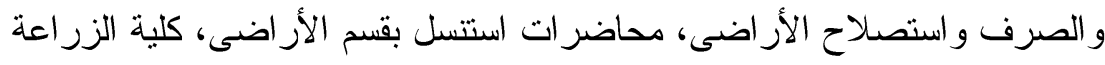
بكفر الثيخ، جامعة طنطا. •r. . شاكر ، محمد حامد زكى، وجمال حسين عامر (2001): بعض المتغيرات المؤثرة على اتجاه

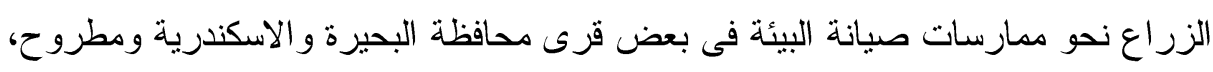
المؤتمر الخامس، أفاق وتحديات الارشاد الزر اعى فى مجال البيئة، الجمعية العلمية للارشاد الزر اعى، المركز المصرى الدولى للزر اعة بالدقى، القاهرة فى الفترة من 24-25 ابريل. 
ا r. . طنطاوى، علام محمد، ومحد عبد الرازق البردان (2010): اتجاه الزراع نحو الزراعة

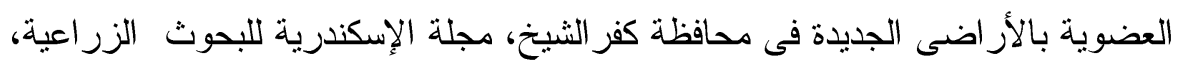

المجلد (55)، العدد الثانى ، أغسطس.

r r. عبدالحافظ، سيد أحمد، وعبدالمنصف عبدالحليم عامر، ومحمود عبدالعليم أبو السعود (2006):

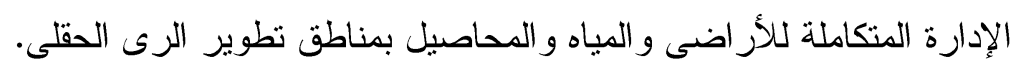

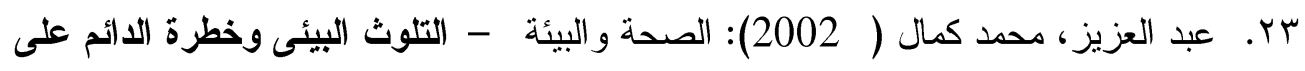
صحتنا، الهيئة المصرية العامة للكتاب، مكتبة الأسرة، القاهرة.

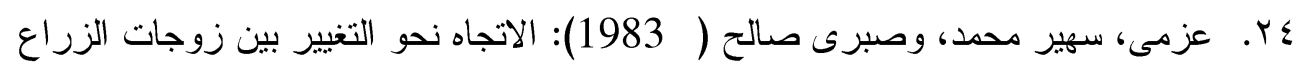

بقرية ميت حبيش القبلية، مركز طنطا بمحافظة الغربية، مجلة الإسكندرية للبحوث الزراعية البهاهية ،

مجلد (38).

هr. فو از، محمود محمد ( 2002): اقتصاديات الأراضى الزر اعية، محاضرات استتسل ، كلية

الزر اعة بكفر الثيخ، جامعة طنطا.

بr. مجلس الوزراء ( 2011): مركز المعلومات ودعم اتخاذ القرار بمحافظة كفر الثيخ، بيانات

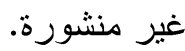

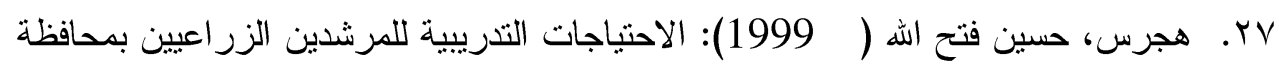

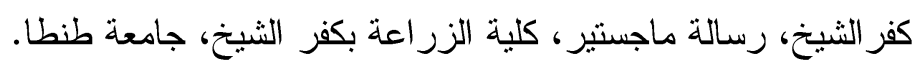

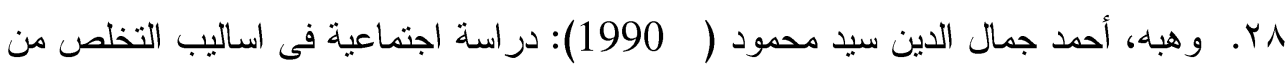

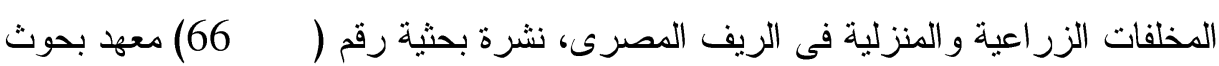

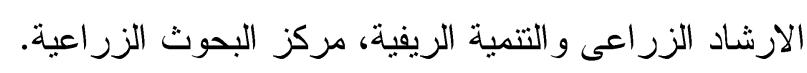

29. Ayers, R.S and Westcot, D.W.(1985): Water Quality For Agriculture, Irrigation and Drainage Paper, 29. Food and Agriculture Organization (FAO) OF U.N. Rome, Italy.

30. Freedman, J.L,M. Carismith and D.O. Sears, (1970): Social Psychology, New York, Holt, Rinehart and Winston, INC.

31. Milteon, Chairs R., (1981): Human Behavior in Organization, Three Leveis Behavior, University of South Calorina, Prentice-Hall, INC., Englewood Cliffs, New Jersey, U.S.A.

32. Otsan, J.M.\& Zanna, M.p., (1991): Attitude Hovge and Attitude Behavior Consistency, in: Baren, B,M. Graziana, W.G\& Stranger, C. Social Psychology, Fort Worth, Holt, Rinehart and Winston. 
علام محد طنطاوى ، لمياء سعد الحسينى

\title{
DETERMINANTS OF FARMERS' ATTITUDES TOWARD FARM LAND CONSERVATION AND IMPROVEMENT PRACTICES IN SOME VILLAGES IN BEHEIRA, GHARBIA, AND KAFR EL-SHEIKH GOVERNORATES
}

\section{LAMIA SAAD ALHUSSEINI and ALLAM MOHAMED TANTAWY}

Agricultural Extension \& Rural Development Research Institut - Department of Rural Sociology Research

(Manuscript received 13 January 2013 )

\begin{abstract}
This research aimed at determining farmer ' $\mathrm{s}$ attitudes toward farm land maintenance and improvement practices' testing the differences in attitudes between villages to identify the relative importance of independent variables in explaining variance in the farmers attitudes and to identify suggestions of farmers that encourage them to improve and maintain farm land .To achieve the objectives of the research. Random sample of 300 farmers was selected from the three villages of Abo el- Mag, Behir, Mahalla ElQasab, Kafr El-sheikh, and Moatamedia, Gharbia . Data were collected during the May, June 2012 by personal interviews. Means, F-test, Simple correlation and Multiple regression were used for data analysis.
\end{abstract}

\section{The most important results could be summarized as follows:}

1- Approximately one half of the respondents had positive attitudes toward farm land improvement and maintenance practices, While the other half of respondents had neutral or negative attitudes.

2- The variables of educational level, farming experience sources of the environmental agricultural information, monthly household income, facilities of the community, belonging to the local communit, value of agricultural soil, knowledge about damage caused by environmental practices correlated significantly with attitudes toward farm land improvement and maintenance practices.

3- The independent variables, explained togather $54 \%$ of the variation in attitudes towards farm land improvement and maintenance practices however, there are 
six variables explain about $52.8 \%$ of the variance these are educational level, farming experience community facilities, belonging to the local community, value of agricultural land and the, knowledge about damage caused by environmental pollution practices.

4- The most important suggestions that encourage farmers to improve and maintain farm land are: teaching environmental courses in all levels of education including maintaining farm land ( $81.41 \%$ ) raising awareness with the importance of farm land and its value(77.5\%), severe sanctions and law inforcement against misuse and for building on farm land (75.96\%) in view of these results, seven recommendations were stated. 